NBER WORKING PAPER SERIES

\title{
CHEAP LABOR MEETS COSTLY CAPITAL: THE IMPACT OF DEVALUATIONS ON COMMODITY FIRMS
}

\author{
Kristin J. Forbes \\ Working Paper 9053 \\ http://www.nber.org/papers/w9053 \\ NATIONAL BUREAU OF ECONOMIC RESEARCH \\ 1050 Massachusetts Avenue \\ Cambridge, MA 02138 \\ July 2002
}

Thanks to Sebastian Edwards, Roberto Rigobon, two anonymous referees and participants at the 2001 IASE/NBER meetings and 2 nd Annual IMF Research conference for helpful comments and suggestions. The views expressed herein are those of the author and not necessarily those of the National Bureau of Economic Research.

(C) 2002 by Kristin J. Forbes. All rights reserved. Short sections of text, not to exceed two paragraphs, may be quoted without explicit permission provided that full credit, including (C) notice, is given to the source. 
Cheap Labor Meets Costly Capital: The Impact of Devaluations on Commodity Firms Kristin J. Forbes

NBER Working Paper No. 9053

July 2002

JEL No. F1, F2, F3

\begin{abstract}
This paper examines how devaluations affect the relative costs of labor and capital and therefore influence production, profitability, investment, and stock returns for firms in the "crisis" country as well as competitors in the rest of the world. After developing these ideas in a small, open-economy model, the paper performs a series of empirical tests using information for about 1,100 firms in 10 commodity industries between 1996 and 2000. The empirical tests support the model's main predictions: 1) Immediately after devaluations, commodity firms in the crisis country have output growth rates about 10\%-20\% higher than competitors in other countries; 2) Immediately after devaluations, commodity firms in the crisis country have operating-profit growth rates about 15\%-25\% higher than competitors in other countries; 3 ) The effect of devaluations on fixed capital investment and stock returns (and therefore expected long-run output and profits) is determined by capital/labor ratios and changes in the cost of capital. For example, crisis-country firms have higher rates of capital growth and better stock performance after devaluations if they had lower capital/labor ratios and there was no substantial increase in their interest rates.
\end{abstract}

Kristin J. Forbes

MIT-Sloan School, Room E52-434

50 Memorial Drive

Cambridge, MA 02142

and NBER

Tel: 617-253-8996

Fax: 617-258-6855

kjforbes@mit.edu

http://web.mit.edu/kjforbes/www 


\section{INTRODUCTION}

In 1997 Indonesia abandoned its pegged exchange rate regime and allowed the rupiah to depreciate substantially. In 1998, Indonesia's economy contracted by about 14 percent. Several companies and industries, however, increased production and profits improved substantially. For example, in 1998 the plantation sector (which includes coffee, cocoa, rubber, palm oil and tea) grew by 6.5 percent. One of the largest plantations in the country reported that profits increased by a multiple of four in the same year. ${ }^{1}$ Over the same period, however, numerous firms complained about a "credit crunch" and their inability to obtain financing to increase their productive capacity and take advantage of lower dollar export prices. Many firms even claimed that they were unable to obtain enough working capital to purchase inputs necessary to continue producing at pre-devaluation levels.

Financial crises not only affect firms in the devaluing country, but can also impact competitors around the world. After Brazil devalued the real in January of 1999, Argentine companies were forced to reduce their export prices for soya beans in order to compete with cheaper Brazilian exports. During the Asian and Russian crises, stock returns for firms that competed with devaluing-country exports were significantly lower than for other firms in the same countries. ${ }^{2}$ This suggests that the Asian and Russian devaluations negatively impacted expected earnings and profits for firms that competed with exports from the crisis countries.

This paper examines how devaluations affect relative costs, production decisions and profitability for firms within a "crisis" country as well as competitors in other countries (where a "crisis" country is defined loosely as a country that devalues its currency). More specifically, it analyzes how devaluations influence firms' output, profitability, capital investment, and stock returns, as well as industry prices and quantities, in the short and long run. In the theoretical model, firms are assumed to use two variable inputs (labor and materials) and one fixed input (capital). Labor is priced in domestic currency. Materials and capital are priced in "dollars," and the price of capital also incorporates any domestic capital market developments. The immediate impact of devaluations is to lower the relative cost of labor in the crisis country. Firms in the devaluing country increase output and profits, while competitors decrease output and profits. In the longer term, however, devaluations raise the cost of capital for firms in the crisis country (potentially by more than the exchange-rate movement). If this increase in the cost of capital is large enough and the firm's capital/labor ratio is high enough, more expensive capital could outweigh the benefits of relatively cheaper labor. Therefore, in the long run, devaluations could

\footnotetext{
${ }^{1}$ Statistics from the Asian Wall Street Journal (1999).

${ }^{2}$ Forbes (2000).
} 
decrease output, profits, and investment for firms in the devaluing country, and increase these variables for competitors in other countries.

The empirical section of the paper uses data for over 1,100 firms in 10 commodity industries to test the model's main predictions during a series of devaluations between 1997 and 2000. Results show that immediately after devaluations, commodity firms in the crisis country have output growth rates about 10\%-20\% higher and profit growth rates about 15\%-25\% higher than competitors in other countries. These growth effects are short-lived and tend to disappear within a year, although the levels of output and profits remain higher indefinitely. Moreover, investment growth and stock returns (both of which signal changes in expected long-term output and profitability) are correlated with capital/labor ratios and changes in the crisis-country cost of capital. For example, crisis-country firms have larger increases in capital investment and better stock performance after devaluations if they had lower capital/labor ratios and their interest rates did not increase substantially. Therefore, although the empirical analysis is not a formal test of the theoretical model, the estimates agree with the model's central predictions. Even though crisis-country firms may benefit from cheaper labor immediately after devaluations, they may not benefit in the longer-term if they use capital intensively and/or their capital becomes more costly.

This paper focuses on firms that produce commodities (or any undifferentiated product) mainly for export. ${ }^{3}$ Although this framework can be extended to other industries, the paper maintains this narrow focus for three reasons. First, commodity exports are a large share of GDP in most countries that abruptly devalue their currency. Moreover, many of these countries rely heavily on commodity exports for tax revenues and foreign currency. Second, although there has been a substantial amount of research on the impact of currency movements on differentiatedgoods firms (such as the pricing-to-market literature), there has been relatively little analysis for homogenous-goods firms. Third and finally, the production structure for most commodities is extremely useful in isolating some of the key effects of devaluations. For example, many commodities require a large, fixed capital investment (such as planting trees or drilling mines) that must be made several years before the resulting output is sold. This structure helps differentiate between the short- and long-run impact of devaluations. Also, the production of most commodities requires imported inputs and capital, as well domestic labor, so that it is possible to capture how devaluations interact with relative input intensities and input costs to affect output, profits, and investment. These factors appear to have played an important role in determining the impact of recent devaluations on firms around the world.

\footnotetext{
${ }^{3}$ Forbes (2002) builds on this analysis by comparing how depreciations affect firm performance for companies producing traded versus non-traded goods or commodities versus differentiated goods.
} 
The remainder of this paper is divided into four sections. Section II reviews several branches of related literature. Section III presents a theoretical model of how devaluations affect firms in the crisis country and rest of the world in the short and long term. It establishes several conditions under which devaluations are more likely to increase firms' output, profitability, and investment levels. Section IV uses firm-level data for a series of devaluations between 1997 and 2000 to test four central predictions of the model. Section V concludes.

\section{LITERATURE REVIEW}

This paper is related to six diverse branches of literature: the impact of devaluations on exports; the effect of financial crises on domestic production; contagion and the international transmission of crises; the importance of exchange-rate exposure to stock returns; the extent of pass-through from currency movements to goods' prices; and the determinants and effects of fluctuations in commodity prices. Each of these branches of literature is so extensive that this survey does not make any attempt to discuss all of the relevant papers. Instead, it simply highlights the key questions and approaches and refers to recent surveys and closely related articles.

The first branch of literature examines how devaluations affect exports. A standard argument justifying devaluations is that they should reduce the relative cost of exports on international markets and therefore improve export growth. There are, however, a number of reasons why devaluations may not have this desired effect, such as if the demand for exports is relatively inelastic or imported inputs are a large component of production. Ghei and Pritchett (1999) provide a detailed summary of why devaluations may or may not improve export performance, as well as why it is difficult to measure these effects. After a review of the empirical work on this subject, they conclude that exports typically increase after a devaluation, and that most of this response occurs rapidly (in about one or two years). ${ }^{4}$

A closely related branch of literature examines how devaluations affect not only exports, but also other variables such as output, investment, and inflation. Agénor and Montiel (1996) provide an excellent summary of this literature and develop a general-equilibrium model showing the various effects of devaluations. They also survey empirical work on this subject and conclude that the evidence on whether devaluations are contractionary is mixed. ${ }^{5}$ More recently, several

\footnotetext{
${ }^{4}$ Several papers have also examined specific examples of how devaluations affect export growth. For example, Duttagupta and Spilimbergo (2000), and Barth and Dinmore (1999) examine the impact of the 1997-98 devaluations on Asian exports.

${ }^{5}$ Edwards (1989) and Kamin (1998) also provide literature surveys and detailed evaluations of the historical evidence on how devaluations impact a variety of macroeconomic variables. Calvo and Reinhart
} 
papers extend this work to examine the impact of "crises" (which are generally defined to include movements in interest rates and/or foreign reserves, as well as exchange rates) on macroeconomic variables. Gupta, Mishra and Sahay (2000) is one of the most recent papers on this subject.

Results suggest that about $40 \%$ of the currency crises between 1970 and 1990 were expansionary.

While these branches of literature focus on the domestic impact of devaluations and crises, a more recent and rapidly growing body of work examines "contagion" and how crises affect other countries. Many of these papers focus on "real" linkages between economies (such as trade competition or shifts in export demand) and/or financial linkages (such as bank lending, mutual fund flows, or changes in investors' beliefs). Claessens and Forbes (2001) includes recent surveys of this literature, as well as a number of case studies and empirical analyses. ${ }^{6}$ While almost all of the empirical work on this subject uses macroeconomic data, one exception that is closely related to this paper is Forbes (2000), which examines how the Asian and Russian crises affected stock returns for over 10,000 companies located around the world. Results suggest that trade linkages are important determinants of how crises are transmitted internationally.

A fourth relevant branch of literature also focuses on stock returns and measures the extent of exchange-rate exposure for various companies. This literature argues that exchange-rate movements can affect stock returns through a number of channels, such as import prices, export prices, and shifts in demand. Rather than estimate each of these channels separately, most papers estimate reduced-form, market models of how exchange-rate movements affect stock returns. Dominguez and Tesar (2001) is one of the most recent and thorough examples of this literature. ${ }^{7}$ They perform an extensive series of tests and conclude that about $12 \%-23 \%$ of firms are significantly exposed to exchange-rate movements. These estimates of fairly low levels of exposure agree with most work on this subject.

A fifth literature closely related to this paper examines how exchange-rate movements affect output prices. This literature includes the work on pricing-to-market and pass-through and emphasizes the role of industrial structure and form of competition. ${ }^{8}$ In certain situations, exchange-rate movements may be wholly absorbed in price-cost margins and have no impact on

(2000) compare the impact of currency crises on macroeconomic variables for emerging markets versus developed countries.

${ }^{6}$ Claessens, Dornbusch, and Park (2001) is an excellent survey of this literature. Glick and Rose (1999) and Forbes (2001) provide evidence of the importance of trade in transmitting crises internationally. Van Rijckeghem and Weder (2001) discuss the role of bank lending, and Kaminsky, Lyons and Schmukler (2000) discuss the role of mutual funds.

${ }_{8}^{7}$ See Bodnar and Wong (2000) for an overview of empirical issues in estimating exchange-rate exposure.

${ }^{8}$ More recently, several papers have extended this framework to examine how exchange-rate movements affect micro-level variables other than prices. For example, Campa and Goldberg (1999) examine the impact of exchange-rate movements on sectoral investment. Klein, Schuh and Triest (2000) and Goldberg and Tracy (1999) examine the impact on wages and employment. 
product prices. Dornbusch (1987) develops these ideas theoretically, and numerous papers have found evidence of pricing-to-market in specific industries. Goldberg and Knetter (1997) is an excellent survey of this empirical literature. They conclude that the impact of exchange-rate movements on local currency prices of foreign products varies by industry, and that for products shipped to the U.S, the average price response is about one-half the exchange-rate movement. ${ }^{9}$

A final literature related to this paper is the extensive work on commodities. For over 150 years economists have tracked commodity prices and attempted to explain their determinants as well as predict future prices. Cashin, McDermott, and Scott (1999) is a recent paper that surveys much of this work and analyzes commodity-price cycles. Other papers have focused on the importance of commodities to various countries, and the impact of commodity price movements on a variety of macroeconomic statistics. For example, Edwards (1986) examines how coffee export prices affect Colombia's real exchange rate. Other papers in the industrial organization or agricultural economics literature have performed detailed analyses of related issues-from the role of cartels to the adoption of new technologies to the impact of El Nino.

Despite the range of theoretical frameworks and empirical tests used in these six branches of literature, none of these papers has explicitly addressed the key question explored in this paper: how do devaluations affect output, profitability and investment decisions of firms around the world? The majority of this literature focuses on macroeconomic relationships and country-level evidence. The literature on exchange-rate exposure and pricing-to-market uses firm-level models and data, but focuses on how exchange-rate movements affect stock returns or product prices. The pricing-to-market literature focuses on differentiated-goods industries in developed countries. Moreover, none of these branches of literature has focused on the key tradeoff analyzed in this paper: how devaluations give exporters a relative cost advantage in terms of cheaper labor and disadvantage in terms of more expensive capital. This tradeoff generates a number of interesting predictions for firms in the devaluing country as well as competitors in the rest of the world.

\section{THE THEORETICAL MODEL}

This section develops a model to show how devaluations affect firms' output, profits, and capital investment in the short and long run. It describes firms that produce any undifferentiated product for export and considers the impact of devaluations on not only firms in the crisis country, but

\footnotetext{
${ }^{9}$ Knetter (1993) and Marston (1990) are two examples of this literature. One noteworthy study that combines this approach with the work on exchange-rate exposure is Allayannis and Ihrig (2000). They examine how market structure, including export and import competitiveness, affects the exchange-rate exposure of a large sample of U.S. firms.
} 
also competitors located elsewhere. Part A models firms' decisions in the short run when their level of capital is fixed. Part B models the long run when firms can adjust their capital levels. Part $\mathrm{C}$ examines the short- and long-run impact of devaluations. This model and framework form the basis of the empirical tests in Section IV. Before developing the model in detail, the next few paragraphs highlight its key components and central predictions.

Each firm uses three inputs (labor, materials, and capital) to produce the same commodity. Firms are located in two "countries," the crisis country (that devalues its currency) and the rest of the world (r.o.w.). Each firm produces a small share of global output and has no impact on global prices. There are no trade barriers or transportation costs. As a result, the commodity's price is determined by global supply and demand. Firms make their production decisions in two stages. In the short run, each firm's level of capital is fixed. This fixed investment could include anything from planting rubber trees to drilling mines. Given this fixed capital, each firm chooses its optimal mix of labor and materials to maximize short-run profits. Labor is priced in domestic currency and can be interpreted as any local component of production, while materials are priced in r.o.w. currency and can be interpreted as imported inputs. Firms have company-specific productivity parameters. In the long term, each firm can also adjust its capital level. Capital is priced in r.o.w. currency and includes a country-specific component (to capture differences in domestic risk and local capital markets).

Each firm chooses its level of capital expecting relative prices and exchange rates to remain constant (at least until the next chance to invest). Then the crisis country devalues its currency. In the short-run, the devaluation reduces the relative cost of labor in the crisis country. This causes crisis-country firms to increase output, lowering the global price of the commodity. Firms in the r.o.w. respond by decreasing production, although by less then the total increase by crisis-country firms. Therefore, the aggregate short-run impact of the devaluation is to increase global production and decrease the price. The magnitude of these effects is determined by the crisis country's share of global production and the share of labor in production. The devaluation also decreases profits for firms in the r.o.w. and increases profits for firms in the crisis country.

Over longer periods, however, firms can adjust their capital levels and the above predictions can be reversed. Since capital is priced in r.o.w. currency, devaluations increase the cost of capital for firms in the crisis country, possibly by even more than the exchange-rate movement if there is a simultaneous increase in domestic risk or contraction in lending. More specifically, if the firm's capital/labor ratio is large enough, or the increase in the cost of capital is large enough, the devaluation could raise the total cost of production for crisis-country firms and outweigh the benefits of relatively cheaper labor. Crisis-country firms would decrease output, 
investment and profits, raising the long-run price of the commodity and causing competitors to increase production, investment and profits. Therefore, although the model's short-run predictions of how devaluations affect output and profits are fairly clear, the long-run predictions depend on firm's capital/labor ratios and relative changes in input costs.

Before developing this model in detail, it is worth mentioning what the model does not consider. First, it does not allow for any sort of strategic pricing behavior. Firms are assumed to take the global output price as given and are unable to affect this price by adjusting production or forming cartels. Similarly, exchange-rate movements are fully passed through into material input prices. Second, although exogenous shocks can affect global demand for the commodity in each period, the model assumes that firms export most of their output, so there is no direct impact of the devaluation on global demand. Finally, all prices are in real terms and the real impact of the devaluation on relative prices is not eroded by differences in inflation rates across countries.

\section{III.A. The Short-Run with a Fixed Level of Capital ${ }^{10}$}

In order to produce most commodities, firms must make a large, upfront investment in fixed capital. After making this initial investment, there is often a substantial time lag before the first unit of output is sold. For example, there is about a six-year lag after coffee is planted until the beans can be sold. To capture this, I model firms' decisions in two stages. In the short-run, defined as the periods from $t=1 \ldots T$, a firm's level of capital is fixed. In the long run when $t>T$ (which is modeled in part B), a firm is able to choose its level of capital. ${ }^{11}$

Beginning with this short-run scenario, each firm $i$ has a fixed level of capital $k_{i}>0$. Output in each period $t$ is determined by the choice of two variable inputs: domestic labor $\left(l_{i, t}\right)$ and imported materials $\left(m_{i, t}\right)$. Firm output is given by a Cobb-Douglas production function that has decreasing returns to scale ${ }^{12}$ :

$$
q_{i, t}=A_{i} k_{i}^{\alpha} l_{i, t}^{\beta} m_{i, t}^{\gamma} \quad \text { with } \alpha+\beta+\gamma<1 \text {. }
$$

$A_{i}$ is a technology parameter (which varies across firms). The cost of labor is $w_{t}$ and of materials is $s_{t}$. The firm chooses variable inputs to maximize short-run profits $\left(\pi_{i, t}^{S R}\right)$ in each period:

$$
\underset{l, m}{\operatorname{Max}} \pi_{i, t}^{S R}=P_{t} q_{i, t}-w_{t} l_{i, t}-s_{t} m_{i, t}
$$

\footnotetext{
${ }^{10}$ This short-run version of the model is loosely based on Dornbusch (1987).

${ }^{11}$ Although the model does not explicitly include entry and exit, firms can set output and capital to zero in the long run and therefore "exit". Entry is captured by allowing firms to increase their capital levels.

${ }^{12}$ Decreasing returns to scale ensures that the most efficient firm does not produce all of global output.
} 
where $P_{t}$ is the sale price per unit of output.

Each firm produces identical goods and there is no differentiation between markets (i.e. no barriers to trade or transportation costs). Therefore, the global price of the good can be expressed as a function of global output $\left(Q_{t}\right)$, and to simplify the model's solution, assume that this global price is determined by a constant-elasticity demand function:

$$
P_{t}=Z_{t} Q_{t}^{-\varphi}
$$

where $Z_{t}$ is any period-specific shock to global demand and $1 / \varphi$ is the elasticity of demand. ${ }^{13}$ Moreover, assume that each firm produces a relatively small fraction of global output and therefore takes input costs and the industry price as given. These assumptions are fairly accurate descriptions of competition in most commodity industries.

Without loss of generality, assume that firms are located in two "countries": the crisis country (which will devalue its currency) and the rest of the world (r.o.w.). In the notation that follows, all variables for the crisis country that differ from the r.o.w. are written with a " $\sim$ ", and firms in the crisis country are indexed by $j$. The output price $(P)$ and cost of imported materials $(s)$ are both expressed in r.o.w. currency, which can be interpreted as dollars. In the short run, the only price that differs between the two countries is the domestic wage. The exchange rate is the relative cost of labor in the two countries,

$$
e_{t}=\frac{\tilde{w}_{t}}{w_{t}}
$$

so that a devaluation in the crisis country is a decrease in $e$. If the r.o.w. wage is normalized to equal one, then the production function and profit-maximization equation for firms in the crisis country (corresponding to equations 1 and 2 for firms in the r.o.w) are:

$$
\begin{aligned}
& \tilde{q}_{j, t}=A_{j} \tilde{k}_{j}^{\alpha} \tilde{l}_{j, t}^{\beta} \tilde{m}_{j, t}^{\gamma} \quad \text { and } \\
& \underset{\tilde{l}, \tilde{m}}{\operatorname{ax}} \tilde{\pi}_{j, t}^{S R}=P_{t} \tilde{q}_{j, t}-e_{t} \tilde{l}_{j, t}-s_{t} \tilde{m}_{j, t} .
\end{aligned}
$$

Combining equations (1) through (6), for a fixed level of investment and given output price, each firm chooses its optimal combination of the two variable inputs in order to maximize profits in period $t$. The optimal output levels for firms in the r.o.w. and crisis country are:

\footnotetext{
${ }^{13}$ The commodity is a normal good, so that $\varphi>0$.
} 


$$
q_{i, t}^{S R}=\left[P_{t}^{\beta+\gamma} A_{i} k_{i}^{\alpha}\left(\frac{\beta}{w_{t}}\right)^{\beta}\left(\frac{\gamma}{s_{t}}\right)^{\gamma}\right]^{1 / 1-\beta-\gamma} \text { and } \quad \tilde{q}_{j, t}^{S R}=\left[P_{t}^{\beta+\gamma} A_{j} \tilde{k}_{j}^{\alpha}\left(\frac{\beta}{e_{t}}\right)^{\beta}\left(\frac{\gamma}{s_{t}}\right)^{\gamma}\right]^{1 / 1-\beta-\gamma} \text {. }
$$

Next, in order to obtain the global output price and quantity, assume that there are $n$ firms in the r.o.w, and $\tilde{n}$ firms in the crisis country. Global output can be expressed as:

$$
Q_{t}=\int_{i=1}^{n} q_{i, t}+\int_{j=1}^{\tilde{n}} \tilde{q}_{j, t}
$$

The appendix presents the full solutions for the global price and quantity. The equations have the appealing result that in the short-run, price is determined by the variable cost of production in each country (which is determined by productivity levels and fixed capital investment) weighted by total output in each country.

\section{III.B. The Long-Run with Variable Capital}

In periods longer than $T$, firms can adjust their capital levels. Capital is priced in r.o.w. currency, but prices vary across countries due to factors such as domestic risk, capital market liquidity, capital controls, etc. Firms chose their optimal levels of capital $\left(k_{i} \geq 0\right.$ and $\left.\tilde{k}_{j} \geq 0\right)$ at cost $r_{t}$ and $\tilde{r}_{t}$ to maximize long-run profits $\left(\pi_{T}^{L R}\right)$ until the next opportunity to invest. To simplify the algebra, assume that there is no discounting. The profit-maximization equations are:

$$
\begin{aligned}
& \underset{k}{\operatorname{Max} \pi_{i, t}^{L R}}=E\left[\int_{t=1}^{T}\left(P_{t} q_{i, t}-w_{t} l_{i, t}-s_{t} m_{i, t}\right)-r k_{i}\right] \\
& \underset{\widetilde{k}}{\operatorname{Max}} \tilde{\pi}_{j, t}^{L R}=E\left[\int_{t=1}^{T}\left(P_{t} \tilde{q}_{j, t}-e_{t} \tilde{l}_{j, t}-s_{t} \tilde{m}_{j, t}\right)-\tilde{r} \tilde{k}_{j}\right] .
\end{aligned}
$$

Next, assume that companies expect input prices and demand shocks to be constant (so that $\mathrm{E}\left[w_{t}\right]=w, \mathrm{E}\left[e_{t}\right]=e, \mathrm{E}\left[s_{t}\right]=s$, and $\mathrm{E}\left[Z_{t}\right]=Z$ ). Then prices from $t=1$ to $T$ are expected to be constant and $\mathrm{E}\left[\mathrm{P}_{t}\right]=P$. Substituting the short-run solutions into equations (9) and (10), the optimal capital investment for firms in the r.o.w. and crisis country are:

$$
k_{i}=\zeta\left(\frac{A_{i} P}{w^{\beta}{ }_{s} \gamma_{r}^{1-\beta-\gamma}}\right)^{\frac{1}{1-\beta-\gamma-\alpha}} \text { and } \quad \tilde{k}_{j}=\zeta\left(\frac{A_{j} P}{e^{\beta_{s} \gamma_{\tilde{r}}^{1-\beta-\gamma}}}\right)^{\frac{1}{1-\beta-\gamma-\alpha}} \text {. }
$$

with $\zeta=f(\alpha, \beta, \gamma, T)$. As a result, firms will chose higher capital levels if: they are more productive, the expected output price is higher, or any of the input prices are lower. 
Using (11) it is possible to solve for each firm's optimal long-run output. As long as the price realizations are equal to their expected values, the long-run output solutions are:

$$
q_{i, t}^{L R}=\Psi\left(\frac{A_{i} P^{\beta+\gamma+\alpha}}{w^{\beta}{ }_{s} \gamma^{\alpha}}\right)^{1 / 1-\beta-\gamma-\alpha} \text { and } \quad \tilde{q}_{j, t}^{L R}=\Psi\left(\frac{A_{j} P^{\beta+\gamma+\alpha}}{e^{\beta}{ }^{\gamma} \tilde{r}^{\alpha}}\right)^{1 / 1-\beta-\gamma-\alpha}
$$

with $\Psi=f(\alpha, \beta, \gamma, T)$. The solutions for the long-run global quantity and price are reported in the Appendix. The long-run price is determined by the total cost of production in each country (which is a function of average productivity and input prices) weighted by output in each country.

\section{III.C. The Impact of Devaluations on Firms around the World}

Using the model developed above, it is possible to predict the impact of devaluations on firms in the crisis country and r.o.w. in both the short run (when capital is fixed) and the long run (when capital is adjustable). Assume that there is an unexpected devaluation that has no impact on global demand for the commodity (i.e. that $\left.d Z_{t} / d e_{t}=0\right) .{ }^{14}$ In the short-run, the main impact is to reduce the relative cost of labor in the crisis country. The top of Table 1 reports the predicted impact of devaluations on global output and prices and shows that devaluations (a decrease in $e$ ) cause global output to increase and prices to fall. These effects are proportional to the share of labor in production and the share of global output produced by crisis-country firms.

The next section of Table 1 shows the short-run effect of devaluations on firm output and profits. ${ }^{15}$ Exchange-rate movements affect firms in the r.o.w only through movements in the global commodity price. Therefore, devaluations cause r.o.w. firms to reduce output and profits. On the other hand, exchange-rate movements affect crisis-country firms through two channels in the short run: the global commodity price and the relative cost of labor. The first effect is the same as for firms in the r.o.w. Counteracting this "output-price" effect, however, is an "inputprice" effect. Devaluations reduce the cost of labor in the crisis country relative to the cost of other inputs, as well as relative to firms in the r.o.w. Algebraic manipulation shows that this second "input-price" effect always dominates the first "output-price" effect, so that devaluations unambiguously cause crisis-country firms to increase output in the short run. Finally, since global output increases and output by the r.o.w. decreases, output by the crisis country must increase by

\footnotetext{
${ }^{14}$ This assumption is realistic for commodity firms in most emerging markets since the majority of production is exported to developed countries, and most devaluations have minimal impact on their demand. In select cases, such as the 1998 Russian crisis, this assumption may not apply. It is straightforward to extend the model and allow exchange-rate movements to affect global demand.

${ }^{15}$ Short-run profits do not include the cost of capital investment and are defined in equations (2) and (6).
} 
even more than the increase in global production. Therefore, firms in the crisis country will sell to customers/markets that were previously serviced by firms in the r.o.w.

Devaluations will also increase short-run profits for firms in the crisis country, with one additional caveat: if the global elasticity of demand for the product is greater than one and/or if the crisis country has a small enough share of global output. In other words, if the price decline leads to a large enough increase in global demand, or if the impact on global prices is fairly small (since the crisis country only produces a small fraction of global output), then devaluations increase short-run profits for crisis-country firms. There is a lengthy debate in the development literature on whether the elasticity condition $(1 / \varphi>1)$ holds for most commodities. Estimates of the price elasticity of demand are highly dependent on an individual commodity's characteristics, how narrowly it is defined, and the length of time constituting "short run". In most cases, however, the output-share condition $\left(\hat{Q}_{t}^{\text {Crisis,SR }} / \hat{Q}_{t}^{\text {World,SR }}<X\right)$ is satisfied because the production of most commodities is widely dispersed across countries. ${ }^{16}$ Moreover, even for commodities with extremely low price elasticities of demand, this condition should be satisfied. ${ }^{17}$ Therefore, devaluations are expected to increase short-run profits for firms in the crisis country.

Over the longer term, however, the short-run impact of devaluations on output and profits can be reversed. Devaluations also affect the relative cost of capital, and when $t \geq T$, firms can adjust their investment accordingly. More specifically, assume that:

$$
\frac{d r_{t}}{d e_{t}}=0 \quad \text { and } \quad \frac{d \tilde{r}_{t}}{d e_{t}}<0
$$

In other words, devaluations have no impact on the cost of capital for r.o.w. firms but increase the cost for crisis-country firms. This increase could occur because $\mathrm{f}$ capital investment is financed in r.o.w. currency and/or imported, then the crisis-country interest rate would move in proportion to the devaluation. If devaluations also raise domestic interest rates by increasing the country risk premium, contracting bank lending, and/or decreasing property and collateral values, then interest rates in the crisis country could increase by significantly more than the exchange-rate movement.

\footnotetext{
${ }^{16}$ Even when a country is heavily specialized in a specific commodity, it rarely has a dominant share of global production. Agénor and Montiel (1996) make this point and document that only 16 developing countries have as much as $10 \%$ of the world market for any commodity (based on 3-digit SITC groups).

${ }^{17}$ For example, if $\varphi=5$ so that the price elasticity of demand for the commodity is 0.2 (which is unrealistically low), and $\beta+\gamma=0.5$ (which is also unrealistically low for an emerging market), then $X=.60$. In other words, even using extreme parameter values which make it more difficult to satisfy this condition, a country would have to produce over 60 percent of global production in order for $\hat{Q}_{t}^{\text {Crisis,SR }} / \hat{Q}_{t}^{\text {World,SR }}>X$.
} 
The middle of Table 1 shows the predicted long-run impact of an exchange-rate movement on global output and prices. Devaluations can either increase or decrease global output and prices based on two conditions: the relative share of labor and capital in production and the impact on the crisis-country's cost of capital. If labor is a more important component of production than capital and/or if the impact of the devaluation on interest rates is small, then the devaluation is more likely to increase global production and decrease global prices. The equations also show the intuitive result that the impact of devaluations on global output and prices is greater (in either direction) when the crisis country produces a larger share of global output.

The long-run impact of devaluations on firm output, capital, and profits is shown at the bottom of Table 1. Exchange-rate movements continue to affect output and profits for r.o.w. firms, as well as investment levels, only through movements in the global commodity price. Therefore, a devaluation could cause r.o.w. firms to either increase or decrease their output and investment, based on whether the devaluation leads to a long-run increase or decrease in the global price as determined by the above criteria. If production is relatively more capital intensive, or if the devaluation causes a large increase in interest rates, then there is a greater chance that the global price increases and r.o.w. firms subsequently increase output and investment.

Finally, as shown at the bottom of Table 1, devaluations affect output, profits, and capital for crisis-country firms through the same global price effect as for r.o.w. firms, as well as through changes in the relative costs of labor and capital. Algebraic manipulation, however, shows that the sign of the impact depends on the same two criteria: capital-labor ratios and changes in the crisis-country cost of capital. Devaluations only increase output, investment, and profits for crisis-country firms in the long run if: labor's share is relatively larger than capital's share and the increase in the cost of capital is not too large. ${ }^{18}$ This is an intuitive result. Devaluations will only cause crisis-country firms to increase output, investment and profits if the cost advantage gained from relatively cheaper labor is greater than the cost disadvantage from relatively more expensive capital. Therefore, in the long run devaluations will have the opposite impact on output, investment, and profits for firms in the crisis country versus firms in the r.o.w.

\footnotetext{
${ }^{18}$ The impact of devaluations on capital and profits in crisis-country firms also depends on the elasticity and/or global output share criteria. As discussed above, however, these conditions are expected to be satisfied since commodity production is rarely concentrated in an individual country.
} 


\section{EMPIRICAL TESTS}

This section tests four of the model's key predictions. Part A describes the data set, devaluation episodes, and commodity groups used for the analysis. Parts B and C examine how devaluations affect output growth and profit growth, respectively. Parts D and E assess the expected long-run impact by examining changes in firms' investment and stock returns. These two sections also consider how capital/labor ratios and changes in the cost of capital determine the impact of devaluations on different groups of firms. Although this empirical analysis is not a formal test of the full theoretical model, the results support the model's central predictions for how devaluations impact output, profitability, and investment for firms around the world.

\section{IV.A. The Events, Data, and Commodity Groups}

The empirical analysis focuses on "major devaluations" in 8 countries between January 1, 1997 and December 31, 1999. "Major devaluations" are defined as episodes where the local currency/U.S. dollar exchange rate increased by 15 percent or more within any 4-week period.

Table 2 lists the countries with major devaluations in chronological order, as well as the month of the devaluation. ${ }^{20}$ This list of devaluation episodes includes the standard events typically analyzed in the currency-crisis literature: several Asian countries in 1997-98, South Africa and Russia in 1998, and Brazil in 1999.

The empirical tests focus on 10 commodity groups: natural rubber and related forest products; mining for silver and gold ores; natural gas and crude petroleum; preserved fruits and vegetables; edible oils and fats; cigarettes; industrial inorganic chemicals; plastics, materials and synthetics; industrial organic chemicals; and fertilizers. ${ }^{21}$ The firm-level information includes data for over 1,100 firms and is from the Worldscope database published by Primark (2001). Table 3 shows the distribution of firms (and average firm size) by country and region. Although the sample includes information from 51 countries and 9 regions, coverage of many developing economies is extremely limited. (For example, there is only 1 firm for Jordan, Luxembourg,

\footnotetext{
${ }^{19}$ This period was chosen to correspond with the available firm-level data. The exchange-rate data is from Datastream.

${ }^{20}$ After a devaluation, the next four weeks are excluded so that there can be, at most, one devaluation event within any 4-week period. The only major devaluation that is not included in this analysis is for Ecuador starting in January of 1999. This event is excluded because there is no firm-level data for Ecuador and Ecuador exports less than 1 percent of global exports for each of the commodity groups in the sample.

${ }^{21}$ These commodity groups were chosen based on three criteria: (1) firm-level data existed for at least 20 companies in the 3-digit industry; (2) at least 5 percent of the firms in the industry were located in devaluing countries; (3) the industry roughly fits the characteristics of a commodity as described in the model. Several of the resulting industry groups are not typical commodities, but as shown in the sensitivity tests, results are robust to excluding different commodities.
} 
Morocco, Peru, and Zimbabwe.) Table 4 provides additional information on the distribution of firms by commodity group in the devaluing countries, as well as corresponding 3-digit SIC codes.

The remainder of this section uses the 10 commodity groups listed in Table 4 to examine the impact of the devaluation events listed in Table 2 on output, profits, investment, and stock returns in firms around the world. It focuses on the model's predictions for firms, rather than industries, because global production and prices are affected by numerous shocks to supply and demand (other than devaluations) that are extremely difficult to measure. For example, an unusually cold winter in the Northern hemisphere can increase demand for natural gas and oil; a severe monsoon in Asia could decrease the global supply of edible oils; and technological advances (such as fiberoptics) can reduce the demand for specific minerals (such as copper). By focusing on within-industry differences in firm performance, rather than on aggregate industry trends, it is possible to control for these exogenous shocks to global supply and demand and better identify the direct impact of devaluations on firms around the world.

\section{IV.B. Test of Prediction 1: The Short-run Impact of Devaluations on Firm Output}

Model Prediction 1: Immediately after devaluations, commodity-exporting firms in the devaluing country increase output and competing firms in other countries decrease output.

To test this prediction, Table 5 begins by listing average output growth for firms in countries that devalued (in that year) compared to competitors in countries that did not devalue. Output growth is measured as the annual percent change in net sales and revenues (measured in local currency) for each year from 1996 through $2000 .^{22}$ The first row of the table reports mean output growth for the entire sample. The lower rows disaggregate average output growth into the 10 commodity groups in Table 4. The table also reports standard deviations of output growth (in parentheses) and z-statistics from a Wilcoxon rank-sum test of the null hypothesis that the two independent samples of firms are from populations with the same distribution.

Table 5 shows that average annual output growth for firms in devaluing countries was 21 percent, while output growth for firms in non-devaluing countries was 8 percent. When output growth is disaggregated by commodity group, firms in devaluing countries have higher output growth in all 10 industries. For example, in the edible oils and fats industry, output growth for firms in devaluing countries averaged 16 percent, while output growth for firms in non-devaluing countries averaged only 4 percent. Moreover, the z-statistics are significant (at the 10 percent level) for the entire sample of firms and for 9 of the 10 commodity groups. These tests indicate

\footnotetext{
${ }^{22}$ More specifically, net sales and revenues are defined as gross sales and other operating revenues less discounts, returns and allowances.
} 
that output growth rates for firms in devaluing countries are significantly higher than for firms in non-devaluing countries.

Next, in order to formalize this analysis and control for inflation, annual shocks to output, and any forward and/or lagged impact of devaluations, I estimate the model:

$$
\Delta q_{i, t}=\theta_{0}+\theta_{1} \text { Devalue }_{i, t-1}+\theta_{2} \text { Devalue }_{i, t}+\theta_{3} \text { Devalue }_{i, t+1}+\theta_{4} \text { Inflation }_{i, t}+\boldsymbol{\eta}_{t}+\varepsilon_{i, t}
$$

where $\Delta q_{i, t}$ is output growth for company $i$ in period $t$; Devalue $_{i, t-l}$ is a dummy variable equal to 1 if the country where firm $i$ is located will have a devaluation in the next period; Devalue $e_{i, t}$ is a dummy variable equal to 1 if the country where firm $i$ is located devalued in period $t$; Devalue $_{i, t+1}$ is a dummy variable equal to 1 if the country where firm $i$ is located devalued in the previous period; Inflation ${ }_{i, t}$ is the inflation rate for the country where firm $i$ is located in period $t ; \eta_{t}$ is a vector of period dummy variables (for 1996 through 1999, with 2000 the excluded year); and $\varepsilon_{i, t}$ is an error term. The Devalue $_{i, t-1}$ variable captures whether firms had higher or lower output growth in the year before a devaluation, while Devalue $e_{i, t}$ and Devalue $e_{i, t+1}$ capture whether firms had significantly different output growth in the year of the devaluation or year immediately following. The inflation variable captures any impact of changes in the price level on reported output growth. ${ }^{23}$ The period dummy variables capture any global shifts in supply or demand that affect all firms in the sample in any period.

Table 6 reports estimates of equation (14). The first row shows results when the model is estimated as a pooled cross-section of firms in all 10 commodity groups. The second and third rows report results when the model is estimated with fixed or random industry effects. The bottom part of the table reports estimates when equation (14) is estimated separately for each of the commodities. When the model is estimated for the entire sample, Devalue $e_{i, t}$ is always positive and significant at the 1 percent level. This suggests that when a country devalues its currency, domestic firms have significantly higher output growth (in that year) than firms in non-devaluing countries. The size of this effect can be large. The pooled cross-section estimates indicate that annual output growth is 11 percent greater, on average, for firms in the devaluing country. Moreover, when equation (14) is estimated separately for each of the 10 commodity groups, the coefficients on Devalue $_{i, t}$ remain positive for each of the industries (and are significant at the 10 percent level in 40 percent of the industries). This suggests that within most industries, firms in devaluing countries had higher output growth than competitors in non-devaluing countries. For

\footnotetext{
${ }^{23}$ Inflation is measured as the annual percent change in the consumer price index as reported in line 64..xzf of International Monetary Fund (2001). The reporting period is adjusted to correspond to the firm's financial year.
} 
example, estimates for the first commodity group indicate that output growth for rubber plantations was 27 percent greater in devaluing countries than for competitors located elsewhere.

When the model is estimated for the entire sample of firms, the coefficients on the forward and lagged devaluation variables are always negative (and the coefficient on one is significant). The estimates in the lower section of the table, however, show that the sign of these estimates fluctuates across industries. Moreover, coefficient estimates for the natural gas and crude petroleum group are such large negative outliers that they could be driving the large negative coefficients for the entire sample. ${ }^{24}$ To test this, the first row of Table 7 repeats the base results (using random effects) from the top of Table 6 and then Row 2 excludes firms in the natural gas and crude petroleum industry. The coefficients on Devalue $e_{i,-1}$ and Devalue $e_{i, t+1}$ are now positive and insignificant, while the coefficient on Devalue $_{i, t}$ remains positive and highly significant. Next, to examine if any other industry groups affect these estimates, I re-estimate the model excluding one commodity group at time (both with and without the natural gas and crude petroleum industry). In each case, the coefficient on Devalue ${ }_{i, t}$ is positive and highly significant, and the signs and significance of the coefficients on Devalue $_{i, t-1}$ and Devalue $e_{i, t+1}$ depend on the industries included in the analysis.

The remainder of Table 7 reports a sample of additional sensitivity tests. Row 3 adds a control variable for firm size and Row 4 measures inflation using an index of producer prices instead of consumer prices. Rows 5 and 6 include regional and country dummy variables, respectively. Row 7 excludes OECD countries. Rows 8 and 9 report results for only middle- or low-income countries, as defined in World Bank (2001). Row 10 only includes Asia. Row 11 reports results when the equation for output growth is jointly estimated with the equation for profit growth (discussed in Section IV.C.) using a seemingly-unrelated regressions model in order to control for any correlation in the error terms across models. The top of Table 8 reports results when the devaluation dummies are interacted with the size of the exchange-rate movement in the given period (including squared terms to capture any non-linearities). These results suggest that the impact of devaluations on sales growth is nonlinear and increases (at a decreasing rate) with the size of the depreciation. I also examine the impact of including controls for interest rates, as well as excluding each country, each region, each devaluation event, the inflation variable, the period dummy variables, and/or the forward and lagged effect of devaluations.

\footnotetext{
24 The natural gas and crude petroleum industry is frequently an outlier in the range of tests reported below. This could partially reflect the unique aspects of this industry (such as the power of OPEC and the concentration of supply in a turbulent region). This may also reflect the unusual price volatility during 1997 and 1998. Rapid increases in production, an increase in OPEC quotas, a mild winter, and then an unexpected decrease in global growth, all generated an unusually rapid decline in oil prices during the period when most of the countries in the sample experienced major devaluations.
} 
In each of these sensitivity tests, the central results do not change. In the year of devaluations, crisis-country firms have output growth rates about 10\%-20\% higher than competitors in other countries. On the other hand, the negative coefficients on the forward and lagged devaluation variables are not robust. This suggests that firm output growth in the years preceding and following devaluations is not significantly different. Therefore, devaluations appear to generate a one-time increase in firm output growth during the year of the devaluation, and therefore a permanent increase in firm output levels.

\section{IV.C. Test of Prediction 2: The Short-run Impact of Devaluations on Firm Profits}

Model Prediction 2: Immediately after devaluations, commodity-exporting firms in the devaluing country have higher operating profits and competitors in other countries have lower operating profits. $^{25}$

To test this prediction, I use the same strategy as used above to analyze how devaluations affect firms' output growth. Table 9 begins by listing average growth in operating profits for firms in countries that devalued (in the given year) versus firms in countries that did not devalue. Average growth in operating profits is measured as the annual percent change in net sales and revenues minus the cost-of-goods sold. ${ }^{26}$ Operating profits do not include interest expense, depreciation, amortization, or taxes, and are therefore directly comparable to the definition of short-run profits used in the theoretical model.

Table 9 shows that mean annual profit growth for firms in devaluing countries was 23 percent, compared to 8 percent for firms in non-devaluing countries. The z-statistic indicates that this difference is highly significant. When average profit growth is disaggregated by industry, firms in devaluing countries have higher profit growth in 9 of the 10 industries. For example, in the edible oils and fats industry, profits increased 17 percent, on average, for firms in devaluing countries, while profits decreased by 1 percent for firms in the rest of the world. The z-statistics show that these differences are significant (at the 10 percent level) in 6 of the 10 industries.

Next, I estimate the model:

$$
\Delta \pi_{i, t}=\theta_{0}+\theta_{1} \text { Devalue }_{i, t-1}+\theta_{2} \text { Devalue }_{i, t}+\theta_{3} \text { Devalue }_{i, t+1}+\theta_{4} \text { Inflation }_{i, t}+\boldsymbol{\eta}_{t}+\varepsilon_{i, t}
$$

\footnotetext{
${ }^{25}$ Note that the first part of the prediction (for firms in the crisis country) assumes that the devaluing country produces a small share of global output and/or the global price elasticity of demand for the commodity is greater than or equal to 1 .

${ }^{26}$ Net sales and revenues are defined above. The cost of goods sold is the specific or direct manufacturing cost of materials and labor in the production of finished goods.
} 
where $\Delta \pi_{i, t}$ is growth in operating profits for company $i$ in period $t$, and the other variables are defined after equation (14). Results are reported in Table 10 and support the patterns in Table 9. When the model is estimated using a pooled cross-section, fixed- or random-industry effects for the entire sample, operating profit growth for devaluing-country firms is significantly higher than for competitors. Moreover, this effect can be large. The random-effects estimates suggest that operating profit growth was 17 percent higher for firms in devaluing countries. This impact of devaluations on profit growth, however, is not significant in the following year.

When equation (15) is estimated separately for each of the 10 commodity groups, the coefficients on Devalue $_{i, t}$ remain positive for 9 of the industries (and significant at the 10 percent level for half the groups). The natural gas and crude petroleum industry continues to be an outlier. Equally important, the magnitude of the coefficient estimates continues to suggest that the impact of devaluations can be large. For example, profit growth in firms producing edible oils and fats was 20 percent higher in devaluing countries than the rest of the world. The coefficients on the forward and lagged devaluation variables continue to have mixed signs and significance.

To test the robustness of these results, Table 11 repeats the same series of sensitivity tests performed in Table 7. The bottom of Table 8 reports results when the devaluation dummy variables are interacted with the size of the exchange-rate movement. I also repeat the extensive series of tests outlined in Section IV.B., but not explicitly reported in the tables. In each of these regressions, the central results do not change (although the magnitude of the coefficients fluctuates). Immediately after devaluations, firms in the crisis country have profit growth about 15\%-25\% higher than firms in the r.o.w. There is, however, no consistently significant difference in profit growth for firms in the crisis country and r.o.w. in the years immediately before or after devaluations.

\section{IV.D. Test of Prediction 3: The Impact of Devaluations on Firm Investment}

Model Prediction 3: After devaluations, commodity-exporting firms in the devaluing country increase capital investment and competing firms in other countries decrease capital investment if: labor's share in output is large relative to capital's share and the increase in the crisis-country's cost of capital is small. ${ }^{27}$

Since changes in capital investment signal expected changes in future output, and since the model's conditions for firms to increase or decrease long-run output are identical to the conditions for firms to increase or decrease investment, tests of this prediction can also be

\footnotetext{
${ }^{27}$ The first part of the prediction also assumes that the devaluing country produces a small share of global output and/or the global price elasticity of demand for the commodity is greater than or equal to 1 .
} 
interpreted as signaling the long-run impact of devaluations on output. ${ }^{28}$ For comparability with the previous two sections, and as a preliminary analysis of this prediction, Table 12 reports mean growth in capital investment for firms in devaluing and non-devaluing countries. Growth in capital investment is measured as the annual percent change in net plant, property and equipment. ${ }^{29}$ In contrast to Tables 5 and 9 (which perform this comparison for output and profit growth), there is no clear pattern for firms in devaluing countries versus firms in the r.o.w. Capital growth is virtually identical for the two groups of firms, and there is no consistent pattern across industries when the analysis is disaggregated by commodity. The z-statistics suggest that any difference across the two groups of firms is never significant at the 5 percent level. Moreover, if I estimate the regression model of equations (14) and (15) with growth in capital investment (instead of output or profits) as the dependent variable, the devaluation dummies predicting capital growth are highly insignificant.

These patterns are not surprising. The model's predictions for how devaluations affect short-run output and profits were unambiguous; devaluations would increase short-run output and profits for firms in the devaluing country, and decrease short-run output and profits for firms in the r.o.w. On the other hand, the model's predictions for how devaluations affect investment were ambiguous and depended on capital/labor ratios and changes in the cost of capital. Therefore, unless all industries had similar capital/labor ratios and devaluations had the same effect on interest rates in all of the crisis countries, there is no reason to expect devaluations to have the same effect on capital growth in these diverse countries and firms.

To explore whether capital/labor ratios and the crisis-country cost of capital are related to changes in investment as predicted in the model, the left side of Table 13 compares capital growth rates for different sets of firms in the devaluing countries. The first two lines divide the sample based on whether the cost of capital in the crisis country increased by more or less than 15 percent after the devaluation. ${ }^{30}$ Firms in countries with a larger increase in interest rates have slightly lower capital growth rates (as expected) - although the difference is insignificant. The next two lines divide the sample based on whether the firm's capital/labor ratio was greater or

\footnotetext{
${ }^{28}$ Unfortunately, since the long run in the model is the amount of time before any new investment affects production (which can be several years for commodities), data is not yet available to directly analyze the long-run impact of the devaluations listed in Table 2. Moreover, the firm-level dataset does not have sufficient historical coverage to examine devaluations that occurred before 1996.

${ }^{29}$ Gross plant, property and equipment (PPE) is defined as tangible assets with an expected useful life greater than 1 year which are expected to be used to produce goods for sale or for distribution of services. Net PPE excludes accumulated reserves from depreciation, depletion, and amortization.

${ }^{30}$ The cost of capital is measured by the lending interest rate from line 60P..zf of International Monetary Fund (2001). Data is not available for Brazil, so I substitute the money market rate (line 60B..zf).
} 
less than $400 .^{31}$ Firms with higher capital/labor ratios have slower capital growth rates than firms with lower capital/labor ratios (as also expected). Finally, the last four lines compare capital growth rates for firms with different combinations of capital/labor ratios and changes in interest rates. The results support the model's main predictions. Devaluing country firms with low capital/labor ratios and no significant increase in interest rates had the highest investment growth (15 percent), while firms with high capital/labor ratios and a large increase in interest rates had the slowest investment growth (10 percent).

\section{IV.E. Test of Prediction 4: The Long-run Impact of Devaluations on Firm Profits}

Model Prediction 4: After devaluations, commodity-exporting firms in the devaluing country have higher long-run profits and competing firms in other countries have lower long-run profits if: labor's share in output is large relative to capital's share and the increase in the crisis-country's cost of capital is small. ${ }^{32}$

If firms' stock prices are based on the total present value of expected future earnings, then the impact of devaluations on firms' stock prices should capture the expected impact of devaluations on firms' future earnings. Therefore, in order to test how devaluations are expected to affect firms' long-run profits (for which data is not yet available), this section examines how devaluations affect different companies' stock market returns. Granted, stock returns are an imperfect measure since they can be affected by numerous factors other than a devaluations such as changes in the discount rate or any sort of investor overreaction. On the other hand, stock returns have the advantage of being widely available at a high enough frequency that it is possible to isolate the impact of different devaluations that occur near each other in time.

As an initial test, Table 14 reports mean stock returns for firms in each of the devaluing countries. Returns are calculated as the total return over the 3-month period starting on the first day of the month prior to the devaluation and ending on the last day of the month after the devaluation. ${ }^{33}$ For each devaluation, the sample is divided into two groups: firms with low

\footnotetext{
${ }^{31}$ A capital/labor ratio of 400 is close to the mean ratio for all firms in devaluing countries. Capital/labor ratios are calculated as the ratio of total assets (in US\$) to total employees. Total assets are the sum of total current assets, long-term receivables, investment in unconsolidated subsidiaries, other investments, and net PPE. For several firms, information on employees was not available. For these companies, I substitute the average capital/labor ratio for all firms in the same 3-digit industry for the same country. If no data is available for that industry and country, I substitute the average capital/labor ratio for firms in the same industry for the closest comparable country (based on per capita income and geographic location).

${ }^{32}$ Note that the first part of the prediction (for firms in the crisis country) assumes that the devaluing country produces a small share of global output and/or the global price elasticity of demand for the commodity is greater than or equal to 1 .

${ }^{33}$ I focus on 3-month returns to control for any unexpected movements directly before the devaluation, as well as to allow enough time for investors to fully incorporate information after the event.
} 
capital/labor ratios and firms with high capital/labor ratios. The cutoff between the two groups is the median ratio for that country (so that the two groups are approximately equally sized).

Finally, the shaded rows at the bottom of the table report average stock returns for the entire sample of low capital-intensity and high capital-intensity firms.

Most of the patterns in Table 14 agree with the model's predictions. For the entire sample of crisis countries, as well as for 6 of the 8 devaluations, firms with higher capital/labor ratios had worse stock performance than firms with lower ratios. For example, the unweighted estimates suggest that the average 3-month stock return for firms with higher capital/labor ratios was $-34 \%$, while the return for firms with lower capital/labor ratios was $-21 \%$. Although the majority of firms experienced negative returns during this period, these statistics suggest that investors expected profits for more labor-intensive firms to be less adversely affected by the devaluations than the profits of more capital-intensive firms.

As discussed in Section IV.D., however, the model predicts that it is not only firms' capital/labor ratios, but also changes in their cost of capital that determine how devaluations affect long-term profits. Therefore, the right side of Table 13 examines stock returns for different groups of devaluing-country firms divided based on these two criteria. Firms in countries with a larger increase in interest rates or higher capital/labor ratio have substantially worse stock performance. Firms with lower capital/labor ratios located in countries with no substantial increase in interest rates have the best stock performance (an average 3-month return of -6\%), while firms with higher capital/labor ratios located in countries with a large increase in interest rates have the worst performance (an average return of -29\%).

As a final analysis, Table 15 examines the impact of devaluations on stock returns for firms located outside of the crisis countries. Since many of these devaluations occurred simultaneously, it is difficult to isolate the impact of each individual event. Therefore, this table focuses on cross-industry differences in capital/labor ratios to help identify how devaluations interact with capital/labor ratios to affect firms around the world. More specifically, the first column lists average capital/labor ratios for all firms in the crisis countries by commodity group, in order of increasing capital/labor intensity. The columns on the right list annual returns for all firms in non-devaluing countries from June 1997 through June 1998 (the Asian devaluations) and from July 1998 through July 1999 (the non-Asian devaluations). Unweighted and weighted averages are reported at the bottom of the table, where "low K/L" firms are the 5 industries with the lowest $\mathrm{K} / \mathrm{L}$ ratios, and "high $\mathrm{K} / \mathrm{L}$ " firms are the 5 industries with the highest $\mathrm{K} / \mathrm{L}$ ratios.

Although the correlation is far from perfect, the table indicates that firms in nondevaluing countries that competed with more labor-intensive goods had worse stock performance 
after devaluations than firms which competed with more capital-intensive goods. For example, between June 1997 and June 1998, firms that competed with the most labor-intensive industry (silver and gold mining) had stock returns of -66 percent, while firms that competed with the most capital-intensive industry (natural gas and crude petroleum) had stock returns of -11 percent. The weighted means across all industries (during the same period) suggest that firms which competed with the most labor-intensive industries had mean annual returns of $-37 \%$, while firms that competed with more capital-intensive industries had mean returns of $-13 \%$. These results suggest that firms are more likely to be negatively affected by devaluations if they compete with crisis-country exports that are more labor-intensive.

\section{CONCLUSIONS}

When a country devalues its currency, some firms and countries generally benefit from any resulting changes in relative prices, while other firms and countries are relatively unaffected or suffer a loss in competitiveness. This paper explores a number of conditions determining the impact of devaluations on commodity firms around the world. It focuses on how devaluations affect relative input costs and therefore competitiveness in global markets. In the theoretical model, the immediate impact of devaluations is to lower the relative cost of labor in the crisis country. This improves the competitiveness of firms in the devaluing country, so that they increase output and have higher profits. Devaluations also reduce the relative competitiveness of firms in non-devaluing countries, so that they reduce output and have lower short-run profits.

Devaluations also raise the relative cost of capital for firms in the crisis country, however, potentially by even more than the exchange-rate movement if the devaluation causes a large increase in domestic risk or contraction in lending. In fact, if this increase in the cost of capital for crisis-country firms is large enough, or if firms use capital intensively, then the disadvantage from more costly capital could outweigh the benefits of relatively cheaper labor. Devaluations could cause crisis-country firms to decrease output and profits, while non-crisis firms would increase output and profits. On the other hand, if firms in the devaluing countries have lower capital/labor ratios and there is little impact of the devaluation on the domestic cost of capital, the benefits from cheaper labor will outweigh the disadvantage of more costly capital. Devaluing-country firms would increase output and profitability in the long run, and firms in other countries would decrease output and profitability.

After developing these theoretical concepts, this paper uses data for over 1,100 firms in 10 commodity groups between 1996 and 2000 to test four of the model's key predictions. 
Although the empirical analysis is not a formal test of the full model, estimates support the main conclusions. Immediately after devaluations, firms in crisis countries have output growth rates about 10\%-20\% higher and profit growth rates about 15\%-25\% higher than competitors in nondevaluing countries. These effects are short-lived, however, and disappear within one year (although the level of output and profits remains higher indefinitely). On the other hand, the impact of devaluations on capital investment and stock returns (and therefore expected long-run output and profits) is correlated with changes in interest rates and capital/labor ratios in the crisis country. More specifically, crisis-country firms with lower capital/labor ratios in countries without a large increase in interest rates have higher investment growth rates and better stock performance after devaluations. These results are intuitive. Firms are more likely to lose competitiveness after devaluations, and therefore decrease their productive capacity and have lower stock returns, if they are more reliant on capital, and/or if capital becomes significantly more expensive.

Therefore, although devaluations appear to unambiguously benefit this group of crisiscountry, commodity firms in the short run, the long-term effects are ambiguous. The critical determinants of whether crisis-country firms benefit from devaluations are whether the cost advantage from cheaper domestic labor outweighs the cost disadvantage from more costly capital. Although this paper does not attempt to aggregate these firm-level effects to the macroeconomic level, the results could provide important insights on why some devaluations boost exports, improve economic growth, and spread to other countries, while other devaluations have little effect on the trade balance, are contractionary, and have minimal impact on the rest of the world. 


\section{Appendix: Model Solutions for Aggregate Prices and Quantities}

This appendix reports the solutions for the aggregate variables in the model developed in Section III in both the short and long run. Define $\bar{q}$ and $\overline{\tilde{q}}$ as the average quantity produced by each firm in the r.o.w. and crisis country, respectively. Then the total quantity produced and industry price can be written as:

$$
Q_{t}=n \bar{q}_{t}+\tilde{n} \overline{\tilde{q}}_{t}
$$

Substituting the short-run solutions from Section III.A.:

$$
\begin{gathered}
Q_{t}^{S R}=\xi_{t}\left[n\left(\frac{\bar{A} \bar{k}^{\alpha}}{s_{t}^{\gamma} w_{t}^{\beta}}\right)^{1 / 1-\beta-\gamma}+\tilde{n}\left(\frac{\overline{\tilde{A}} \overline{\tilde{k}}^{\alpha}}{s_{t}^{\gamma} e_{t}^{\beta}}\right)^{1 / 1-\beta-\gamma}\right]^{(1-\beta-\gamma) /(1-\beta-\gamma)+\varphi(\beta+\gamma)} \\
P_{t}^{S R}=\xi_{t}^{\prime}\left[n\left(\frac{\bar{A} \bar{k}^{\alpha}}{s_{t}^{\gamma} w_{t}^{\beta}}\right)^{1 / 1-\beta-\gamma}+\tilde{n}\left(\frac{\tilde{\tilde{A}} \tilde{\bar{k}}^{\alpha}}{s_{t}^{\gamma} e_{t}^{\beta}}\right)^{1 / 1-\beta-\gamma}\right]^{-\varphi(1-\beta-\gamma) /(1-\beta-\gamma)+\varphi(\beta+\gamma)} \\
\text { where } \xi_{t}=\left(Z_{t}^{\beta+\gamma} \beta^{\beta} \gamma^{\gamma}\right)^{1 / 1-\beta-\gamma+\varphi(\beta+\gamma)} \text { and } \xi_{t}^{\prime}=\left[\frac{Z_{t}^{1-\beta-\gamma}}{\left(\beta^{\beta} \gamma^{\gamma}\right)^{\varphi}}\right]^{1 / 1-\beta-\gamma+\varphi(\beta+\gamma)} .
\end{gathered}
$$

$\bar{A}, \bar{k}, \overline{\tilde{A}}$, and $\overline{\widetilde{k}}$ are the productivity parameters and investment levels for the mean-quantity producing firm in the r.o.w. and crisis country, respectively. The equation for $Q_{t}^{S R}$ yields the intuitive result that global output of the commodity in the short run is greater for: a lower cost of either variable input; a greater number of firms in either country; or a larger average output for firms in either country (which is, in turn, determined by average productivity levels and the amount of fixed investment.) The equation for $P_{t}^{S R}$ shows that the global price is greater for a higher cost of either variable input or lower aggregate output from either country. The formula also has the appealing result that in the short-run, price is determined by the variable cost of production in each country weighted by total output in each country.

In the long run, capital levels can be adjusted and the global quantity and price is:

$$
Q^{L R}=\Phi\left[n\left(\frac{\bar{A}}{w^{\beta}{ }^{\gamma} r^{\alpha}}\right)^{1 / 1-\beta-\gamma-\alpha}+\tilde{n}\left(\frac{\overline{\tilde{A}}}{e^{\beta}{ }^{\gamma} \tilde{r}^{\alpha}}\right)^{1 / 1-\beta-\gamma-\alpha}\right]^{\frac{(1-\beta-\gamma-\alpha-\alpha)}{(1-\beta-\varphi)+(\beta+\gamma+\alpha)}}
$$




$$
P^{L R}=\Phi^{\prime}\left[n\left(\frac{\bar{A}}{w^{\beta} s^{\gamma} r^{\alpha}}\right)^{1 / 1-\beta-\gamma-\alpha}+\tilde{n}\left(\frac{\overline{\tilde{A}}}{e^{\beta} s^{\gamma} \tilde{r}^{\alpha}}\right)^{1 / 1-\beta-\gamma-\alpha}\right]^{\frac{-\varphi(1-\beta-\gamma-\alpha-\alpha)+\varphi(\beta+\gamma+\alpha)}{(1-\beta-\gamma)}}
$$

where:

$$
\Phi=\left[\mathrm{Z}^{\beta+\gamma+\alpha}\left(\beta^{\beta} \gamma^{\gamma} \zeta^{\alpha}\right)^{1-\beta-\gamma-\alpha} / 1-\beta-\gamma\right]^{1 / 1-\beta-\gamma-\alpha+\varphi(\beta+\gamma+\alpha)}
$$

and

$$
\Phi^{\prime}=\left[\frac{\mathrm{Z}}{\left(\beta^{\beta} \gamma^{\gamma} \zeta^{\alpha}\right)^{\varphi / 1-\beta-\gamma}}\right]^{1-\beta-\gamma-\alpha / 1-\beta-\gamma-\alpha+\varphi(\beta+\gamma+\alpha)} .
$$

The equation for $Q^{L R}$ yields the intuitive result that global output is greater for: a lower cost of any of the three inputs; a greater number of firms in either country; or a larger average output level in either country (which is, in turn, determined by average productivity levels). The equation for $P^{L R}$ shows that the global price is greater for a higher cost of any input or a lower aggregate output level in either country. The formula also has the appealing result that in the long run, the global price is determined by the total cost of production in each country weighted by total output in each country. 


\section{REFERENCES}

Agénor, Pierre-Richard and Peter Montiel. (1996). Development Macroeconomics. Princeton, NJ: Princeton University Press.

Allayannis, George and Jane Ihrig. (2000). "The Effect of Markups on the Exchange Rate Exposure of Stock Returns." Board of Governors of the Federal Reserve System, International Finance Discussion Paper \#661.

Asian Wall Street Journal. (1999). "Indonesian Commodities Traders Fear Election Boost for Rupiah.” May $28^{\text {th }}$, pg. 23.

Barth, Marvin and Trevor Dinmore. (1999). "Trade Prices and Volumes in East Asia Through the Crisis." Board of Governors of the Federal Reserve System, International Finance Discussion Papers \#643.

Bodnar, Gordon and M.H. Franco Wong. (2000). "Estimating Exchange Rate Exposures: Some 'Weighty' Issues." NBER Working Paper \# 7497.

Calvo, Guillermo and Carmen Reinhart. (2000). "Fixing for Your Life." NBER Working Paper \#8006.

Campa, Jose and Linda Goldberg. (1999). "Investment, Pass-through and Exchange Rates: A Cross-Country Comparison.” International Economic Review 40 (2, May): 287-314.

Cashin, Paul, John McDermott, and Alasdair Scott. (1999). "Booms and Slumps in World Commodity Prices." IMF Working Paper \#WP/99/155.

Claessens, Stijn, Rudiger Dornbusch and Yung Chul Park. (2001). "Contagion: Why Crises Spread and How This Can Be Stopped." In Stijn Claessens and Kristin Forbes, eds., International Financial Contagion. Norwell, MA: Kluwer Academic Publishers, pgs. 19-41.

Claessens, Stijn and Kristin Forbes. (2001). International Financial Contagion. Norwell, MA: Kluwer Academic Publishers.

Disclosure. (2001). Worldscope-Compact D for Windows. Database on CD-ROM.

Dominguez, Kathryn and Linda Tesar. (2001). "Exchange Rate Exposure." NBER Working Paper \#8453.

Dornbusch, Rudiger. (1987). "Exchange Rates and Prices." American Economic Review 77(1, March): 93-106.

Duttagupta, Rupa and Antonio Spilimbergo. (2000). "What Happened to Asian Exports During the Crisis?" Mimeo.

Edwards, Sebastian. (1989). Real Exchange Rates, Devaluation, and Adjustment. Cambridge, MA: The MIT Press.

Edwards, Sebastian. (1986). "Commodity Export Prices and the Real Exchange Rate in Developing Countries: Coffee in Colombia," in Sebastian Edwards and Liaquat Ahamed, eds. 
Economic Adjustment and Exchange Rates in Developing Countries. Chicago: University of Chicago Press, pgs. 235-260.

Forbes, Kristin (2002). "How Do Large Depreciations Affect Firm Performance?” MIT Mimeo.

Forbes, Kristin (2001). "Are Trade Linkages Important Determinants of Country Vulnerability to Crises?" In Sebastian Edwards and Jeffrey Frankel, eds. Currency Crises Prevention.

Forthcoming.

Forbes, Kristin (2000). “The Asian Flu and Russian Virus: Firm-Level Evidence on How Crises are Transmitted Internationally.” NBER Working Paper \#7807.

Ghei, Nita and Lant Pritchett. (1999). "The Three Pessimisms: Real Exchange Rates and Trade Flows in Developing Countries." In Lawrence Hinkle and Peter Montiel, eds. Exchange Rate Misalignment: Concepts and Measurement for Developing Countries. New York: Oxford University Press, pgs. 467-496.

Glick, Reuven and Andrew Rose. (1999). "Contagion and Trade: Why Are Currency Crises Regional?" Journal of International Money and Finance 18: 603-617.

Goldberg, Linda and Joseph Tracy. (1999). "Exchange Rates and Local Labor Markets." NBER Working Paper \#6985.

Goldberg, Pinelope and Michael Knetter. (1997). "Goods Prices and Exchange Rates: What Have WE Learned?" Journal of Economic Literature. XXXV (3, September): 1243-1272.

Gupta, Poonam, Deepak Mishra and Ratna Sahay. (2000). "Output Response During Currency Crises." IMF mimeo.

International Monetary Fund. (2001). International Financial Statistics. March CD-ROM.

Kamin, Steven. (1988). "Devaluation, External Balance and Macroeconomic Performance: A Look at the Numbers." Study in International Finance no. 62. Princeton University.

Kaminsky, Graciela, Lyons, Richard and Schmukler, Sergio. (2000). "Managers, Investors, and Crises: Mutual Fund Strategies in Emerging Markets." NBER Working Paper \#7855.

Klein, Michael, Scott Schuh, and Robert Triest. (2000). "Job Creation, Job Destruction, and the Real Exchange Rate." NBER Working Paper \#7466.

Knetter, Michael. (1993). "International Comparisons of Pricing-to-Market Behavior." American Economic Review 83(3, June): 473-786.

Marston, Richard. (1990). "Pricing to Market in Japanese Manufacturing." Journal of International Economics 29 (November): 217-36.

Van Rijckeghem, Caroline and Beatrice Weder. (2001). "Sources of Contagion: Is it Finance or Trade?" Journal of International Economics 54(2): 293-308.

World Bank. (2001). World Development Report. New York: Oxford University Press. 
Table 1: Model Predictions for the Impact of Devaluations

\begin{tabular}{|c|c|c|c|}
\hline & Sign & Magnitude & Caveats \\
\hline \multicolumn{4}{|c|}{ Short-Run Predictions } \\
\hline$\frac{d Q_{t}^{S R}}{d e_{t}}$ & $<0$ & $-\Gamma \frac{\beta}{e_{t}} \frac{\hat{Q}_{t}^{C, S R}}{\left(\hat{Q}_{t}^{W, S R}\right)^{\varphi(\beta+\gamma) / 1-\beta-\gamma+\varphi(\beta+\gamma)}}$ & \\
\hline$\frac{d P_{t}^{S R}}{d e_{t}}$ & $>0$ & $\Gamma^{\prime} \frac{\beta}{e_{t}} \frac{\hat{Q}_{t}^{C, S R}}{\left(\hat{Q}_{t}^{W, S R}\right)^{1-\beta-\gamma+\varphi} / 1-\beta-\gamma+\varphi(\beta+\gamma)}$ & \\
\hline$\frac{d q_{i, t}^{S R}}{d e_{t}}$ & $>0$ & $\left(\frac{q_{i, t}^{S R}}{1-\beta-\gamma}\right)\left(\frac{(\beta+\gamma)}{P_{t}^{S R}} \frac{d P_{t}^{S R}}{d e_{t}}\right)$ & \\
\hline$\frac{d \tilde{q}_{j, t}^{S R}}{d e_{t}}$ & $<0$ & $\left(\frac{\tilde{q}_{j, t}^{S R}}{1-\beta-\gamma}\right)\left(\frac{(\beta+\gamma)}{P_{t}^{S R}} \frac{d P_{t}^{S R}}{d e_{t}}-\frac{\beta}{e_{t}}\right)$ & \\
\hline$\frac{d \pi_{i, t}^{S R}}{d e_{t}}$ & $>0$ & $\left(\frac{\pi_{i, t}^{S R}}{1-\beta-\gamma}\right)\left(\frac{1}{P_{t}^{S R}} \frac{d P_{t}^{S R}}{d e_{t}}\right)$ & \\
\hline$\frac{d \tilde{\pi}_{j, t}^{S R}}{d e_{t}}$ & $<0$ & $\left(\frac{\tilde{\pi}_{j, t}^{S R}}{1-\beta-\gamma}\right)\left(\frac{1}{P_{t}} \frac{d P_{t}^{S R}}{d e_{t}}-\frac{\beta}{e_{t}}\right)$ & if $1 / \varphi>1$ and/or $\frac{\hat{Q}_{t}^{C, S R}}{\hat{Q}_{t}^{W, S R}}<\frac{1-\beta-\gamma+\varphi(\beta+\gamma)}{\varphi}$ \\
\hline \multicolumn{4}{|c|}{ Long-run Predictions } \\
\hline$\frac{d Q_{t}^{L R}}{d e_{t}}$ & $?$ & $-\Lambda\left(\frac{\beta}{e_{t}}+\frac{\alpha}{\tilde{r}_{t}} \frac{d \tilde{r}_{t}}{d e_{t}}\right) \frac{\hat{Q}_{t}^{C, L R}}{\left(\hat{Q}_{t}^{W, L R} \frac{\varphi(\beta+\gamma+\alpha)}{1-\beta-\gamma-\alpha+\varphi(\beta+\gamma+\alpha)}\right.}$ & $<0$ if $\frac{\beta}{e_{t}}>\frac{\alpha}{\widetilde{r}_{t}} \frac{d \tilde{r}_{t}}{d e_{t}}$ \\
\hline$\frac{d P_{t}^{L R}}{d e_{t}}$ & $?$ & $A^{\prime}\left(\frac{\beta}{e_{t}}+\frac{\alpha}{\widetilde{r}_{t}} \frac{d \widetilde{r}_{t}}{d e_{t}}\right) \frac{\hat{Q}_{t}^{C, L R}}{\left(\hat{Q}_{t}^{W, L R}\right) \frac{1-\beta-\gamma-\alpha+\varphi}{1-\beta-\gamma-\alpha+\varphi(\beta+\gamma+\alpha)}}$ & $>0$ if $\frac{\beta}{e_{t}}>\frac{\alpha}{\widetilde{r}_{t}} \frac{d \widetilde{r}_{t}}{d e_{t}}$ \\
\hline$\frac{d q_{i, t}^{L R}}{d e_{t}}$ & ? & $\left(\frac{q_{i, t}^{L R}}{1-\beta-\gamma-\alpha}\right)\left(\frac{(\beta+\gamma+\alpha)}{P_{t}^{L R}} \frac{d P_{t}^{L R}}{d e_{t}}\right)$ & $>0$ if $\frac{\beta}{e_{t}}>\frac{\alpha}{\tilde{r}_{t}} \frac{d \widetilde{r}_{t}}{d e_{t}}$ \\
\hline$\frac{d k_{i, t}^{L R}}{d e_{t}}$ & ? & $\left(\frac{k_{i, t}^{L R}}{1-\beta-\gamma-\alpha}\right)\left(\frac{1}{P_{t}^{L R}}\right)\left(\frac{d P_{t}^{L R}}{d e_{t}}\right)$ & $>0$ if $\frac{\beta}{e_{t}}>\frac{\alpha}{\widetilde{r}_{t}} \frac{d \tilde{r}_{t}}{d e_{t}}$ \\
\hline$\frac{d \pi_{i, t}^{L R}}{d e_{t}}$ & $?$ & $\left(\frac{\pi_{i, t}^{L R}}{1-\beta-\gamma-\alpha}\right)\left(\frac{1}{P_{t}^{L R}} \frac{d P_{t}^{L R}}{d e_{t}}\right)$ & $>0$ if $\frac{\beta}{e_{t}}>\frac{\alpha}{\widetilde{r}_{t}} \frac{d \widetilde{r}_{t}}{d e_{t}}$ \\
\hline$\frac{d \tilde{q}_{j, t}^{L R}}{d e_{t}}$ & $?$ & $\left(\frac{\tilde{q}_{j, t}^{L R}}{1-\beta-\gamma-\alpha}\right)\left(\frac{(\beta+\gamma+\alpha)}{P_{t}^{L R}} \frac{d P_{t}^{L R}}{d e_{t}}-\frac{\beta_{t}}{e_{t}}-\frac{\alpha}{\tilde{r}} \frac{d \tilde{r}}{d e}\right)$ & $<0$ if $\frac{\beta}{e_{t}}>\frac{\alpha}{\widetilde{r}_{t}} \frac{d \widetilde{r}_{t}}{d e_{t}}$ \\
\hline$\frac{d \tilde{k}_{j, t}^{L R}}{d e_{t}}$ & $?$ & $\left(\frac{\tilde{k}_{j, t}^{L R}}{1-\beta-\gamma-\alpha}\right)\left(\frac{1}{P_{t}^{L R}} \frac{d P_{t}^{L R}}{d e_{t}}-\frac{\beta}{e_{t}}-\frac{(1-\beta-\gamma)}{\tilde{r}} \frac{d \tilde{r}}{d e}\right)$ & $<0$ if $\frac{\beta}{e}>\frac{\alpha}{\tilde{r}} \frac{d \tilde{r}}{d e}$ and $\left(\frac{1}{\varphi}>\Theta\right.$ and $/$ or $\left.\frac{\hat{Q}_{t}^{C, L R}}{\hat{Q}_{t}^{W, L R}}<\Theta^{\prime}\right)$ \\
\hline$\frac{d \tilde{\pi}_{j, t}^{L R}}{d e_{t}}$ & $?$ & $\left(\frac{\tilde{\pi}_{j, t}^{L R}}{1-\beta-\gamma-\alpha}\right)\left(\frac{1}{P_{t}} \frac{d P_{t}^{L R}}{d e_{t}}-\frac{\beta}{e_{t}}-\frac{\alpha}{\tilde{r}} \frac{d \tilde{r}}{d e}\right)$ & $<0$ if $\frac{\beta}{e}>\frac{\alpha}{\widetilde{r}} \frac{d \widetilde{r}}{d e}$ and $\left(\frac{1}{\varphi}>\Omega\right.$ and $/$ or $\frac{\hat{Q}_{t}^{C, L R}}{\hat{Q}_{t}^{W, L R}}<\Omega^{\prime}$ \\
\hline
\end{tabular}

Notes: $\quad \hat{Q}_{t}^{R, S R}=n\left(\frac{\bar{A} \bar{k}^{\alpha}}{w^{\beta} s^{\gamma}}\right)^{1 / 1-\beta-\gamma}, \hat{Q}_{t}^{C, S R}=\tilde{n}\left(\frac{\overline{\tilde{A}} \bar{\kappa}^{\alpha}}{e_{t}^{\beta} s^{\gamma}}\right)^{1 / 1-\beta-\gamma}, \hat{Q}_{t}^{W, S R}=\hat{Q}_{t}^{R, S R}+\hat{Q}_{t}^{C, S R}$

$\hat{Q}_{t}^{R, L R}=n\left(\frac{\bar{A}}{w^{\beta} s^{\gamma} r^{\alpha}}\right)^{1 / 1-\beta-\gamma-\alpha}, \hat{Q}_{t}^{C, L R}=\tilde{n}\left(\frac{\overline{\tilde{A}}}{e_{t}^{\beta} s^{\gamma} \widetilde{r}_{t}^{\alpha}}\right)^{1 / 1-\beta-\gamma-\alpha}, \hat{Q}_{t}^{W, L R}=\hat{Q}_{t}^{R, L R}+\hat{Q}_{t}^{C, L R}$,

and $\Gamma, \Gamma^{\prime}, \Lambda, \Lambda^{\prime}, \Theta, \Theta^{\prime}, \Omega, \Omega^{\prime}=f(\alpha, \beta, \gamma, T, Z, \varphi, e, \tilde{r}, d \tilde{r} / d e)$. 


\section{Table 2 \\ Major Devaluation Events ${ }^{\mathrm{a}}$}

\begin{tabular}{lc}
\hline Country & \multicolumn{1}{c}{ Devaluation Period } \\
Thailand & $7 / 97,12 / 97,1 / 98$ \\
Indonesia & $10 / 97,12 / 97,1 / 98,5 / 98,6 / 98,1 / 99$ \\
Philippines & $12 / 97$ \\
South Korea & $12 / 97,1 / 98$ \\
Malaysia & $1 / 98$ \\
South Africa & $7 / 98$ \\
Russia & $8 / 98,10 / 98,12 / 98,1 / 99$ \\
Brazil & $1 / 99$ \\
\hline
\end{tabular}

Notes: (a) "Major devaluations" are episodes when the country's local currency/U.S. dollar exchange rate increases by 15 percent or more within a 4-week period. After a devaluation event, the next four weeks are excluded, so that there can be, at most, one devaluation event within any 4-week period. Exchange rate data is from Datastream.

(b) Countries in the sample which do not have any major devaluation events are: Argentina, Australia, Austria, Bahrain, Bangladesh, Belgium, Britain, Canada, Chile, China, Colombia, Czech Republic, Denmark, Finland, France, Germany, Greece, Hong Kong, Hungary, India, Ireland, Israel, Italy, Japan, Jordan, Kuwait, Lebanon, Luxembourg, Malta, Mexico, Morocco, Netherlands, New Zealand, Norway, Poland, Portugal, Saudi Arabia, Singapore, Slovakia, Spain, Sri Lanka, Sweden, Switzerland, Taiwan, Turkey, United Arab Emirates, Uruguay, and Venezuela. Ecuador is the one country that has a major devaluation but is not included in the list since firm-level data is not available for the country and Ecuador exports less than 1 percent of global exports for each of the commodities studied. 
Table 3: Firm Sample Information

\begin{tabular}{|c|c|c|c|}
\hline Region & Country & \# Firms & Average Asset Value $^{a}$ \\
\hline \multirow[t]{4}{*}{ Africa } & Egypt & 2 & $\$ 106,735$ \\
\hline & Morocco & 1 & 884,222 \\
\hline & South Africa & 51 & 936,165 \\
\hline & Zimbabwe & 1 & 30,146 \\
\hline \multirow[t]{2}{*}{ Australasia } & Australia & 66 & $\$ 392,031$ \\
\hline & New Zealand & 3 & 893,242 \\
\hline \multirow[t]{6}{*}{ East Asia } & Hong Kong & 5 & $\$ 347,789$ \\
\hline & Japan & 140 & $1,799,298$ \\
\hline & Korea & 43 & $1,094,628$ \\
\hline & Malaysia & 49 & 313,508 \\
\hline & Singapore & 10 & 174,846 \\
\hline & Taiwan & 26 & 719,444 \\
\hline \multirow[t]{4}{*}{ Eastern Europe } & Czech Republic & 9 & $\$ 221,110$ \\
\hline & Hungary & 2 & 365,357 \\
\hline & Poland & 3 & 229,511 \\
\hline & Russia & 10 & $3,802,581$ \\
\hline \multirow[t]{7}{*}{ Latin America } & Argentina & 9 & $\$ 2,529,668$ \\
\hline & Brazil & 26 & $2,700,113$ \\
\hline & Chile & 4 & 584,754 \\
\hline & Colombia & 2 & 62,207 \\
\hline & Mexico & 8 & $1,403,361$ \\
\hline & Peru & 1 & 389,694 \\
\hline & Venezuela & 2 & $11,820,064$ \\
\hline \multirow[t]{3}{*}{ Middle East } & Israel & 6 & $\$ 1,177,402$ \\
\hline & Jordan & 1 & 481,423 \\
\hline & Turkey & 5 & 75,959 \\
\hline \multirow[t]{2}{*}{ North America } & Canada & 170 & $\$ 621,109$ \\
\hline & United States & 151 & $3,940,778$ \\
\hline \multirow[t]{6}{*}{ South and West Asia } & China & 9 & $\$ 1,138,498$ \\
\hline & India & 71 & 349,866 \\
\hline & Indonesia & 11 & 528,264 \\
\hline & Pakistan & 20 & 71,352 \\
\hline & Philippines & 13 & 272,038 \\
\hline & Thailand & 18 & 560,326 \\
\hline \multirow[t]{17}{*}{ Western Europe } & Austria & 3 & $\$ 408,174$ \\
\hline & Belgium & 8 & $3,192,222$ \\
\hline & Denmark & 5 & 497,253 \\
\hline & Finland & 3 & $1,376,643$ \\
\hline & France & 15 & $3,593,548$ \\
\hline & Germany & 13 & $9,909,534$ \\
\hline & Greece & 15 & 99,360 \\
\hline & Ireland & 7 & 139,395 \\
\hline & Italy & 10 & $8,175,550$ \\
\hline & Luxembourg & 1 & $8,643,201$ \\
\hline & Netherlands & 7 & $2,933,540$ \\
\hline & Norway & 8 & $3,812,535$ \\
\hline & Portugal & 4 & 91,514 \\
\hline & Spain & 7 & $1,046,979$ \\
\hline & Sweden & 5 & $1,368,383$ \\
\hline & Switzerland & 6 & $3,371,978$ \\
\hline & United Kingdom & 63 & $2,782,784$ \\
\hline Total Sample & & 1,128 & $\$ 1,777,259$ \\
\hline
\end{tabular}

Note: (a) Assets measured in thousands of U.S. dollars in 1996 (or the closest year available). 
Table 4: Sample Information for Devaluing Countries

\begin{tabular}{|c|c|c|c|c|c|c|c|c|c|c|}
\hline \multirow[t]{2}{*}{$\begin{array}{l}\text { Industry and } \\
\text { SIC Code }\end{array}$} & \multicolumn{2}{|c|}{$\begin{array}{c}\text { Natural Rubber \& } \\
\text { Gums/Forest Products } \\
083 \\
\end{array}$} & \multicolumn{2}{|c|}{$\begin{array}{c}\text { Mining for Silver \& } \\
\text { Gold Ores } \\
104 \\
\end{array}$} & \multicolumn{2}{|c|}{$\begin{array}{c}\text { Natural Gas \& } \\
\text { Crude Petroleum } \\
131 \\
\end{array}$} & \multicolumn{2}{|c|}{$\begin{array}{c}\text { Preserved Fruits \& } \\
\text { Vegetables } \\
203 \\
\end{array}$} & \multicolumn{2}{|c|}{$\begin{array}{c}\text { Edible } \\
\text { Oils \& Fats } \\
207 \\
\end{array}$} \\
\hline & \# Firms & $\%$ Total & \# Firms & $\%$ Total & \# Firms & $\%$ Total & \# Firms & $\%$ Total & \# Firms & $\%$ Total \\
\hline Brazil & 0 & 0.0 & 0 & 0.0 & 1 & 0.4 & 1 & 1.2 & 2 & 2.7 \\
\hline Indonesia & 2 & 8.7 & 0 & 0.0 & 0 & 0.0 & 0 & 0.0 & 1 & 1.4 \\
\hline Korea & 1 & 4.3 & 0 & 0.0 & 0 & 0.0 & 2 & 2.5 & 1 & 1.4 \\
\hline Malaysia & 12 & 52.2 & 1 & 0.5 & 0 & 0.0 & 1 & 1.2 & 21 & 28.4 \\
\hline Philippines & 0 & 0.0 & 4 & 2.2 & 7 & 3.0 & 1 & 1.2 & 0 & 0.0 \\
\hline Russia & 0 & 0.0 & 1 & 0.5 & 9 & 3.9 & 0 & 0.0 & 0 & 0.0 \\
\hline South Africa & 0 & 0.0 & 40 & 21.5 & 1 & 0.4 & 1 & 1.2 & 0 & 0.0 \\
\hline Thailand & 0 & 0.0 & 0 & 0.0 & 1 & 0.4 & 4 & 4.9 & 2 & 2.7 \\
\hline $\begin{array}{l}\text { Total crisis firms } \\
\text { Total firms in sample }\end{array}$ & $\begin{array}{l}15 \\
23\end{array}$ & $\begin{array}{c}65.2 \% \\
100.0 \% \\
\end{array}$ & $\begin{array}{c}46 \\
186 \\
\end{array}$ & $\begin{array}{l}24.7 \% \\
100.0 \%\end{array}$ & $\begin{array}{c}19 \\
233 \\
\end{array}$ & $\begin{array}{c}8.2 \% \\
100.0 \% \\
\end{array}$ & $\begin{array}{l}10 \\
81 \\
\end{array}$ & $\begin{array}{l}12.3 \% \\
100.0 \%\end{array}$ & $\begin{array}{l}27 \\
74\end{array}$ & $\begin{array}{l}36.5 \% \\
100.0 \%\end{array}$ \\
\hline & \multicolumn{2}{|c|}{$\begin{array}{c}\text { Cigarettes } \\
211 \\
\end{array}$} & \multicolumn{2}{|c|}{$\begin{array}{c}\text { Industrial Inorganic } \\
\text { Chemicals } \\
281 \\
\end{array}$} & \multicolumn{2}{|c|}{$\begin{array}{c}\text { Plastics, Materials \& } \\
\text { Synthetics } \\
282 \\
\end{array}$} & \multicolumn{2}{|c|}{$\begin{array}{c}\text { Industrial Organic } \\
\text { Chemicals } \\
286 \\
\end{array}$} & \multicolumn{2}{|c|}{$\begin{array}{c}\text { Fertilizer/ } \\
\text { Agricultural Chemicals } \\
287 \\
\end{array}$} \\
\hline SIC Code & \# Firms & $\%$ Total & \# Firms & $\%$ Total & \# Firms & $\%$ Total & \# Firms & $\%$ Total & \# Firms & $\%$ Total \\
\hline Brazil & 1 & 2.4 & 1 & 0.8 & 4 & 2.3 & 7 & 7.0 & 9 & 10.6 \\
\hline Indonesia & 3 & 7.3 & 0 & 0.0 & 2 & 1.1 & 2 & 2.0 & 1 & 1.2 \\
\hline Korea & 1 & 2.4 & 4 & 3.1 & 19 & 10.8 & 8 & 8.0 & 7 & 8.2 \\
\hline Malaysia & 4 & 9.8 & 3 & 2.3 & 4 & 2.3 & 2 & 2.0 & 1 & 1.2 \\
\hline Philippines & 0 & 0.0 & 1 & 0.8 & 0 & 0.0 & 0 & 0.0 & 0 & 0.0 \\
\hline Russia & 0 & 0.0 & 0 & 0.0 & 0 & 0.0 & 0 & 0.0 & 0 & 0.0 \\
\hline South Africa & 1 & 2.4 & 3 & 2.3 & 4 & 2.3 & 1 & 1.0 & 0 & 0.0 \\
\hline Thailand & 0 & 0.0 & 2 & 1.6 & 7 & 4.0 & 1 & 1.0 & 1 & 1.2 \\
\hline Total crisis firms & 10 & $24.4 \%$ & 14 & $10.9 \%$ & 40 & $22.7 \%$ & 21 & $21.0 \%$ & 19 & $22.4 \%$ \\
\hline Total firms in sample & 41 & $100.0 \%$ & 128 & $100.0 \%$ & 177 & $100.0 \%$ & 100 & $100.0 \%$ & 85 & $100.0 \%$ \\
\hline
\end{tabular}

Note: Crisis firms are firms in countries with a major devaluation event between 1996 and 2000 as defined in Table 2. 


\section{Table 5 \\ Trends in Firm Output Growth : \\ Devaluing Countries versus Rest of World}

\begin{tabular}{|c|c|c|c|c|}
\hline & & $\begin{array}{c}\text { Firms in } \\
\text { devaluing } \\
\text { countries }\end{array}$ & $\begin{array}{c}\text { Firms in } \\
\text { rest of } \\
\text { world } \\
\end{array}$ & $\begin{array}{l}\text { Z-statistic for } \\
\text { difference in } \\
\text { output growth }\end{array}$ \\
\hline Full sample & $\begin{array}{l}\text { Mean output growth } \\
\text { Standard deviation }\end{array}$ & $\begin{array}{c}\mathbf{0 . 2 1} \\
(0.50)\end{array}$ & $\begin{array}{c}\mathbf{0 . 0 8} \\
(0.46)\end{array}$ & $-6.50 * *$ \\
\hline $\begin{array}{l}\text { Rubber plantations } \\
\& \text { forest products }\end{array}$ & $\begin{array}{l}\text { Mean output growth } \\
\text { Standard deviation }\end{array}$ & $\begin{array}{c}\mathbf{0 . 2 2} \\
(0.30)\end{array}$ & $\begin{array}{l}\mathbf{- 0 . 0 2} \\
(0.34)\end{array}$ & $-2.41 * *$ \\
\hline Silver \& gold ores & $\begin{array}{l}\text { Mean output growth } \\
\text { Standard deviation }\end{array}$ & $\begin{array}{c}\mathbf{0 . 3 7} \\
(1.00)\end{array}$ & $\begin{array}{c}\mathbf{0 . 0 8} \\
(0.76)\end{array}$ & -0.80 \\
\hline $\begin{array}{l}\text { Natural gas \& } \\
\text { crude petroleum }\end{array}$ & $\begin{array}{l}\text { Mean output growth } \\
\text { Standard deviation }\end{array}$ & $\begin{array}{c}\mathbf{0 . 4 1} \\
(0.96)\end{array}$ & $\begin{array}{c}\mathbf{0 . 2 1} \\
(0.66)\end{array}$ & $-2.20 * *$ \\
\hline $\begin{array}{l}\text { Preserved fruits \& } \\
\text { vegetables }\end{array}$ & $\begin{array}{l}\text { Mean output growth } \\
\text { Standard deviation }\end{array}$ & $\begin{array}{c}\mathbf{0 . 1 3} \\
(0.44)\end{array}$ & $\begin{array}{c}\mathbf{0 . 0 6} \\
(0.21)\end{array}$ & $-1.80 *$ \\
\hline Edible oils \& fats & $\begin{array}{l}\text { Mean output growth } \\
\text { Standard deviation }\end{array}$ & $\begin{array}{c}\mathbf{0 . 1 6} \\
(0.40)\end{array}$ & $\begin{array}{c}\mathbf{0 . 0 4} \\
(0.24)\end{array}$ & $-3.69 * *$ \\
\hline Cigarettes & $\begin{array}{l}\text { Mean output growth } \\
\text { Standard deviation }\end{array}$ & $\begin{array}{c}\mathbf{0 . 2 3} \\
(0.20)\end{array}$ & $\begin{array}{c}\mathbf{0 . 0 9} \\
(0.19)\end{array}$ & $-2.36 * *$ \\
\hline $\begin{array}{l}\text { Industrial inorganic } \\
\text { chemicals }\end{array}$ & $\begin{array}{l}\text { Mean output growth } \\
\text { Standard deviation }\end{array}$ & $\begin{array}{c}\mathbf{0 . 1 0} \\
(0.13)\end{array}$ & $\begin{array}{c}\mathbf{0 . 0 4} \\
(0.17)\end{array}$ & $-1.97 * *$ \\
\hline $\begin{array}{l}\text { Plastics, materials } \\
\& \text { synthetics }\end{array}$ & $\begin{array}{l}\text { Mean output growth } \\
\text { Standard deviation }\end{array}$ & $\begin{array}{c}\mathbf{0 . 1 3} \\
(0.34)\end{array}$ & $\begin{array}{c}\mathbf{0 . 0 3} \\
(0.35)\end{array}$ & $-3.76 * *$ \\
\hline $\begin{array}{l}\text { Industrial organic } \\
\text { chemicals }\end{array}$ & $\begin{array}{l}\text { Mean output growth } \\
\text { Standard deviation }\end{array}$ & $\begin{array}{c}\mathbf{0 . 2 4} \\
(0.34)\end{array}$ & $\begin{array}{c}\mathbf{0 . 0 2} \\
(0.24)\end{array}$ & $-2.80 * *$ \\
\hline Fertilizer & $\begin{array}{l}\text { Mean output growth } \\
\text { Standard deviation }\end{array}$ & $\begin{array}{c}\mathbf{0 . 2 2} \\
(0.23) \\
\end{array}$ & $\begin{array}{c}\mathbf{0 . 1 0} \\
(0.32) \\
\end{array}$ & $-2.10 * *$ \\
\hline
\end{tabular}

Notes: (a) Output growth measured as percent change in net sales and revenues measured in local currency. (b) Devaluing countries are countries with a major devaluation (as defined in Table 2) in the current year.

(c) Z-statistic from a two-sample Wilcoxon rank-sum test if the two groups of firms are from populations with the same distribution. * indicates significance at the 10 percent level and $* *$ indicates significance at the 5 percent level. 


\section{Table 6}

\section{Regression Results: Growth in Firm Output}

\begin{tabular}{|c|c|c|c|c|c|c|}
\hline \multirow{3}{*}{$\begin{array}{l}\text { Pooled cross- } \\
\text { section }\end{array}$} & \multicolumn{3}{|c|}{ Devaluation Dummies } & \multicolumn{3}{|c|}{ \# } \\
\hline & $t-1$ & $\mathbf{t}$ & $t+1$ & Inflation & Observs. & $\mathbf{R}^{2}$ \\
\hline & $\begin{array}{c}-0.106 * * \\
(0.054)\end{array}$ & $\begin{array}{l}0.109 * * \\
(0.038)\end{array}$ & $\begin{array}{l}-0.069 \\
(0.078)\end{array}$ & $\begin{array}{c}0.005 * * \\
(0.001)\end{array}$ & 3,079 & 0.03 \\
\hline $\begin{array}{l}\text { Fixed industry } \\
\text { effects }\end{array}$ & $\begin{array}{c}-0.082 * * \\
(0.040)\end{array}$ & $\begin{array}{c}0.133 * * \\
(0.037)\end{array}$ & $\begin{array}{l}-0.048 \\
(0.051)\end{array}$ & $\begin{array}{c}0.005^{* *} \\
(0.001)\end{array}$ & 3,079 & 0.02 \\
\hline $\begin{array}{l}\text { Random industry } \\
\text { effects }\end{array}$ & $\begin{array}{c}-0.106 * * \\
(0.040)\end{array}$ & $\begin{array}{c}0.109 * * \\
(0.036)\end{array}$ & $\begin{array}{l}-0.069 \\
(0.051)\end{array}$ & $\begin{array}{c}0.005^{* *} \\
(0.001)\end{array}$ & 3,079 & 0.03 \\
\hline $\begin{array}{l}\text { Rubber plantations } \\
\text { \& forest products }\end{array}$ & $\begin{array}{l}0.108 * \\
(0.065)\end{array}$ & $\begin{array}{c}0.266 * * \\
(0.095)\end{array}$ & $\begin{array}{l}0.125 \\
(0.317)\end{array}$ & $\begin{array}{l}0.009 * * \\
(0.002)\end{array}$ & 72 & 0.24 \\
\hline Silver \& gold ores & $\begin{array}{l}-0.081 \\
(0.135)\end{array}$ & $\begin{array}{c}0.359 \\
(0.272)\end{array}$ & $\begin{array}{l}0.145 \\
(0.272)\end{array}$ & $\begin{array}{c}0.006 \\
(0.008)\end{array}$ & 388 & 0.02 \\
\hline $\begin{array}{l}\text { Natural gas \& } \\
\text { crude petroleum }\end{array}$ & $\begin{array}{l}-0.950^{*} \\
(0.503)\end{array}$ & $\begin{array}{c}0.164 \\
(0.296)\end{array}$ & $\begin{array}{l}-0.939 \\
(0.594)\end{array}$ & $\begin{array}{c}0.001 \\
(0.003)\end{array}$ & 613 & 0.10 \\
\hline $\begin{array}{l}\text { Preserved fruits \& } \\
\text { vegetables }\end{array}$ & $\begin{array}{c}0.117 \\
(0.074)\end{array}$ & $\begin{array}{c}0.036 \\
(0.121)\end{array}$ & $\begin{array}{c}-0.220 * * \\
(0.081)\end{array}$ & $\begin{array}{c}0.007 * * \\
(0.001)\end{array}$ & 230 & 0.14 \\
\hline Edible oils \& fats & $\begin{array}{c}0.131 * * \\
(0.043)\end{array}$ & $\begin{array}{l}0.129 * \\
(0.077)\end{array}$ & $\begin{array}{c}0.041 \\
(0.051)\end{array}$ & $\begin{array}{c}0.008^{* *} \\
(0.001)\end{array}$ & 227 & 0.14 \\
\hline Cigarettes & $\begin{array}{c}0.029 \\
(0.047)\end{array}$ & $\begin{array}{c}0.030 \\
(0.060)\end{array}$ & $\begin{array}{c}-0.167 * * \\
(0.042)\end{array}$ & $\begin{array}{l}0.006^{* *} \\
(0.002)\end{array}$ & 128 & 0.16 \\
\hline $\begin{array}{l}\text { Industrial inorganic } \\
\text { chemicals }\end{array}$ & $\begin{array}{c}0.098 * * \\
(0.034)\end{array}$ & $\begin{array}{c}0.056 \\
(0.038)\end{array}$ & $\begin{array}{c}0.039 \\
(0.066)\end{array}$ & $\begin{array}{c}0.004 \\
(0.003)\end{array}$ & 395 & 0.03 \\
\hline $\begin{array}{l}\text { Plastics, materials } \\
\& \text { synthetics }\end{array}$ & $\begin{array}{c}0.036 \\
(0.046)\end{array}$ & $\begin{array}{c}0.078 \\
(0.054)\end{array}$ & $\begin{array}{c}0.061 \\
(0.042)\end{array}$ & $\begin{array}{c}0.005^{* *} \\
(0.001)\end{array}$ & 508 & 0.04 \\
\hline $\begin{array}{l}\text { Industrial organic } \\
\text { chemicals }\end{array}$ & $\begin{array}{l}-0.089 * \\
(0.054)\end{array}$ & $\begin{array}{c}0.150 * * \\
(0.050)\end{array}$ & $\begin{array}{c}0.076 \\
(0.059)\end{array}$ & $\begin{array}{c}0.009 * * \\
(0.002)\end{array}$ & 271 & 0.13 \\
\hline Fertilizer & $\begin{array}{c}0.001 \\
(0.049)\end{array}$ & $\begin{array}{l}0.114^{*} \\
(0.063)\end{array}$ & $\begin{array}{c}-0.063 \\
(0.130)\end{array}$ & $\begin{array}{c}0.006^{* *} \\
(0.001)\end{array}$ & 247 & 0.09 \\
\hline
\end{tabular}

Notes: * indicates significance at the 10 percent level and ** indicates significance at the 5 percent level. Standard errors are in parentheses and are White-adjusted for heteroscedasticity. $\mathrm{R}^{2}$ is the within- $\mathrm{R}^{2}$ for the fixed-effects estimates and the overall- $\mathrm{R}^{2}$ for the random-effects estimates. Period dummy variables are included in each specification and are always jointly significant at the 1 percent level. 


\section{Table 7 \\ Sensitivity Analysis: Growth in Firm Output}

\begin{tabular}{|c|c|c|c|c|c|c|}
\hline & \multicolumn{3}{|c|}{ Devaluation Dummies } & \multirow[b]{2}{*}{ Inflation } & \multirow{2}{*}{$\begin{array}{c}\# \\
\text { Oberys }\end{array}$} & \multirow[b]{2}{*}{$\mathbf{R}^{2}$} \\
\hline & t-1 & $\mathbf{t}$ & $t+1$ & & & \\
\hline $\begin{array}{l}\text { Base Estimates } \\
\text { (random effects) }\end{array}$ & $\begin{array}{c}-0.106^{* *} \\
(0.040)\end{array}$ & $\begin{array}{c}0.109 * * \\
(0.036)\end{array}$ & $\begin{array}{c}-0.069 \\
(0.051)\end{array}$ & $\begin{array}{c}0.005^{* *} \\
(0.001)\end{array}$ & 3,079 & 0.03 \\
\hline $\begin{array}{l}\text { Exclude natural gas } \\
\& \text { crude petroleum }\end{array}$ & $\begin{array}{c}0.014 \\
(0.035)\end{array}$ & $\begin{array}{l}0.115^{* *} \\
(0.032)\end{array}$ & $\begin{array}{c}0.037 \\
(0.045)\end{array}$ & $\begin{array}{c}0.007 * * \\
(0.001)\end{array}$ & 2,466 & 0.03 \\
\hline $\begin{array}{l}\text { Control for firm } \\
\text { size }^{b}\end{array}$ & $\begin{array}{c}-0.108 * * \\
(0.040)\end{array}$ & $\begin{array}{l}0.108 * * \\
(0.036)\end{array}$ & $\begin{array}{l}-0.072 \\
(0.051)\end{array}$ & $\begin{array}{c}0.005^{* *} \\
(0.001)\end{array}$ & 3,074 & 0.03 \\
\hline $\begin{array}{l}\text { Inflation based on } \\
\text { producer-price index }\end{array}$ & $\begin{array}{c}-0.117 * * \\
(0.041)\end{array}$ & $\begin{array}{l}0.142 * * \\
(0.036)\end{array}$ & $\begin{array}{l}-0.067 \\
(0.051)\end{array}$ & $\begin{array}{l}0.002 * * \\
(0.000)\end{array}$ & 2,949 & 0.02 \\
\hline $\begin{array}{l}\text { Include regional } \\
\text { dummy variables }\end{array}$ & $\begin{array}{c}-0.088 * * \\
(0.042)\end{array}$ & $\begin{array}{l}0.136^{* *} \\
(0.038)\end{array}$ & $\begin{array}{l}-0.067 \\
(0.053)\end{array}$ & $\begin{array}{l}0.005^{* *} \\
(0.001)\end{array}$ & 3,079 & 0.04 \\
\hline $\begin{array}{l}\text { Include country } \\
\text { dummy variables }\end{array}$ & $\begin{array}{c}-0.116^{*} \\
(0.061)\end{array}$ & $\begin{array}{l}0.107 * \\
(0.066)\end{array}$ & $\begin{array}{r}-0.069 \\
(0.072)\end{array}$ & $\begin{array}{c}0.005^{* *} \\
(0.002)\end{array}$ & 3,079 & 0.05 \\
\hline $\begin{array}{l}\text { Only non-OECD } \\
\text { countries }\end{array}$ & $\begin{array}{l}-0.084 \\
(0.052)\end{array}$ & $\begin{array}{c}0.125^{* *} \\
(0.051)\end{array}$ & $\begin{array}{l}-0.082 \\
(0.070)\end{array}$ & $\begin{array}{l}0.004 * * \\
(0.001)\end{array}$ & 945 & 0.03 \\
\hline $\begin{array}{l}\text { Only middle income } \\
\text { countries }^{\mathrm{e}}\end{array}$ & $\begin{array}{l}-0.102 * \\
(0.060)\end{array}$ & $\begin{array}{l}0.108^{*} \\
(0.062)\end{array}$ & $\begin{array}{l}-0.154 * \\
(0.087)\end{array}$ & $\begin{array}{l}0.004 * * \\
(0.001)\end{array}$ & 666 & 0.04 \\
\hline $\begin{array}{l}\text { Only low-income } \\
\text { countries }^{\text {e }}\end{array}$ & $\begin{array}{c}0.076 \\
(0.138)\end{array}$ & $\begin{array}{c}0.209 * * \\
(0.095)\end{array}$ & $\begin{array}{l}--- \\
---\end{array}$ & $\begin{array}{l}0.004 * \\
(0.002)\end{array}$ & 347 & 0.08 \\
\hline Only Asia ${ }^{\mathrm{f}}$ & $\begin{array}{l}-0.074 * \\
(0.042)\end{array}$ & $\begin{array}{l}0.115^{* *} \\
(0.036)\end{array}$ & $\begin{array}{l}-0.090 * \\
(0.050)\end{array}$ & $\begin{array}{l}0.005^{* *} \\
(0.001)\end{array}$ & 1,277 & 0.04 \\
\hline $\begin{array}{l}\text { SUR joint estimation } \\
\text { with profit growth }\end{array}$ & $\begin{array}{c}-0.056^{*} \\
(0.033)\end{array}$ & $\begin{array}{c}0.096^{* *} \\
(0.030)\end{array}$ & $\begin{array}{l}-0.017 \\
(0.045)\end{array}$ & $\begin{array}{c}0.005^{* *} \\
(0.001)\end{array}$ & 2,814 & 0.06 \\
\hline
\end{tabular}

Notes: * indicates significance at the 10 percent level and ** indicates significance at the 5 percent level. Standard errors are in parentheses and are White-adjusted for heteroscedasticity. All estimates are random (industry) effects. $\mathrm{R}^{2}$ is the overall- $\mathrm{R}^{2}$. Period dummy variables are included in each specification.

(a) Excludes natural gas and crude petroleum (SIC group 131).

(b) Firm size measured as total assets in U.S. dollars.

(c) Producer-price index based on line 63..zf in International Monetary Fund (2001). Monthly data corresponds to company's reporting period.

(d) Regional dummy variables are the based on the 9 regions listed in Table 3.

(e) Definitions of middle- and low-income countries are based on classifications in World Bank (2000).

(f) Includes East Asia and South/West Asia, as defined in Table 3.

(g) Results from a seemingly-unrelated regressions model including both output growth and profit growth. Coefficient estimates for the profit growth equation are reported in Table 10. 
Table 8

Sensitivity Analysis: Devaluation Dummies Interacted with Exchange Rate Movements

\begin{tabular}{|c|c|c|c|c|c|c|c|c|}
\hline & \multicolumn{5}{|c|}{ Devaluation Dummies Interacted with Exchange Rate Movements ${ }^{\mathrm{a}}$} & \multirow[b]{2}{*}{ Inflation } & \multirow{2}{*}{$\begin{array}{c}\# \\
\text { Observs. }\end{array}$} & \multirow[b]{2}{*}{$\mathbf{R}^{2}$} \\
\hline & t-1 & $\mathbf{t}$ & $\mathbf{t}^{2}$ & $\mathbf{t}+\mathbf{1}$ & $(\mathrm{t}+\mathbf{1})^{2}$ & & & \\
\hline \multicolumn{9}{|c|}{ Dependent Variable: Sales Growth } \\
\hline $\begin{array}{l}\text { Pooled cross- } \\
\text { section }\end{array}$ & $\begin{array}{c}0.113 \\
(0.110)\end{array}$ & $\begin{array}{l}0.368 \\
(0.242)\end{array}$ & $\begin{array}{l}-0.367 \\
(0.266)\end{array}$ & $\begin{array}{c}0.068 \\
(0.263)\end{array}$ & $\begin{array}{l}-0.015 \\
(0.266)\end{array}$ & $\begin{array}{c}0.005^{* *} \\
(0.001)\end{array}$ & 3,079 & 0.02 \\
\hline $\begin{array}{l}\text { Fixed industry } \\
\text { effects }\end{array}$ & $\begin{array}{c}0.024 \\
(0.165)\end{array}$ & $\begin{array}{c}0.536 * * \\
(0.242)\end{array}$ & $\begin{array}{c}-0.596 * * \\
(0.301)\end{array}$ & $\begin{array}{c}0.084 \\
(0.181)\end{array}$ & $\begin{array}{l}-0.067 \\
(0.155)\end{array}$ & $\begin{array}{c}0.006 * * \\
(0.001)\end{array}$ & 3,079 & 0.02 \\
\hline $\begin{array}{l}\text { Random industry } \\
\text { effects }\end{array}$ & $\begin{array}{c}0.113 \\
(0.161)\end{array}$ & $\begin{array}{c}0.368 \\
(0.243)\end{array}$ & $\begin{array}{l}-0.367 \\
(0.302)\end{array}$ & $\begin{array}{c}0.068 \\
(0.180)\end{array}$ & $\begin{array}{l}-0.015 \\
(0.155)\end{array}$ & $\begin{array}{c}0.005 * * \\
(0.001)\end{array}$ & 3,079 & 0.02 \\
\hline \multicolumn{9}{|c|}{ Dependent Variable: Operating Income Growth } \\
\hline $\begin{array}{l}\text { Pooled cross- } \\
\text { section }\end{array}$ & $\begin{array}{c}0.009 \\
(0.256)\end{array}$ & $\begin{array}{c}0.447 \\
(0.301)\end{array}$ & $\begin{array}{l}-0.374 \\
(0.331)\end{array}$ & $\begin{array}{c}0.243 \\
(0.233)\end{array}$ & $\begin{array}{l}-0.080 \\
(0.271)\end{array}$ & $\begin{array}{c}0.005 * * \\
(0.001)\end{array}$ & 2,814 & 0.02 \\
\hline $\begin{array}{l}\text { Fixed industry } \\
\text { effects }\end{array}$ & $\begin{array}{l}-0.134 \\
(0.200)\end{array}$ & $\begin{array}{c}0.680 * * \\
(0.292)\end{array}$ & $\begin{array}{c}-0.689 * * \\
(0.359)\end{array}$ & $\begin{array}{l}0.266 \\
(0.223)\end{array}$ & $\begin{array}{l}-0.149 \\
(0.189)\end{array}$ & $\begin{array}{c}0.006 * * \\
(0.001)\end{array}$ & 2,814 & 0.02 \\
\hline $\begin{array}{l}\text { Random industry } \\
\text { effects }\end{array}$ & $\begin{array}{c}0.009 \\
(0.194)\end{array}$ & $\begin{array}{c}0.447 \\
(0.292)\end{array}$ & $\begin{array}{l}-0.374 \\
(0.360)\end{array}$ & $\begin{array}{c}0.243 \\
(0.222)\end{array}$ & $\begin{array}{l}-0.080 \\
(0.188)\end{array}$ & $\begin{array}{c}0.005 * * \\
(0.001)\end{array}$ & 2,814 & 0.02 \\
\hline
\end{tabular}

Notes: * indicates significance at the 10 percent level and ** indicates significance at the 5 percent level. Standard errors are in parentheses and are Whiteadjusted for heteroscedasticity. $\mathrm{R}^{2}$ is the within- $\mathrm{R}^{2}$ for the fixed-effects estimates and the overall- $\mathrm{R}^{2}$ for the random-effects estimates. Period dummy variables are included in each specification and are always jointly significant at the 1 percent level.

(a) The devaluation dummy variables are interacted with the movement in the US\$ exchange rate of the relevant crisis country for the year of the crisis $(t)$. For the year after the crisis $(t+1)$ the exchange rate movement is the cumulative movement in the US\$ exchange rate in the year of the crisis and year after the crisis. 


\section{Table 9}

\section{Trends in Firm Operating Profits ${ }^{\mathrm{a}}$ : \\ Devaluing Countries versus Rest of World}

\begin{tabular}{|c|c|c|c|c|}
\hline & & $\begin{array}{l}\text { Firms in } \\
\text { devaluing } \\
\text { countries }^{b}\end{array}$ & $\begin{array}{l}\text { Firms in } \\
\text { rest of } \\
\text { world }\end{array}$ & $\begin{array}{l}\text { Z-statistic for } \\
\text { difference in } \\
\text { profit growth }^{c}\end{array}$ \\
\hline Full sample & $\begin{array}{l}\text { Mean profit growth } \\
\text { Standard deviation }\end{array}$ & $\begin{array}{c}\mathbf{0 . 2 3} \\
(0.56)\end{array}$ & $\begin{array}{c}\mathbf{0 . 0 8} \\
(0.54)\end{array}$ & $-5.54 * *$ \\
\hline $\begin{array}{l}\text { Rubber plantations } \\
\& \text { forest products }\end{array}$ & $\begin{array}{l}\text { Mean profit growth } \\
\text { Standard deviation }\end{array}$ & $\begin{array}{c}\mathbf{0 . 0 8} \\
(0.66)\end{array}$ & $\begin{array}{l}\mathbf{- 0 . 0 2} \\
(0.57)\end{array}$ & -0.88 \\
\hline Silver \& gold ores & $\begin{array}{l}\text { Mean profit growth } \\
\text { Standard deviation }\end{array}$ & $\begin{array}{c}\mathbf{0 . 3 3} \\
(1.09)\end{array}$ & $\begin{array}{c}\mathbf{0 . 0 2} \\
(0.81)\end{array}$ & -0.82 \\
\hline $\begin{array}{l}\text { Natural gas \& } \\
\text { crude petroleum }\end{array}$ & $\begin{array}{l}\text { Mean profit growth } \\
\text { Standard deviation }\end{array}$ & $\begin{array}{c}\mathbf{0 . 1 8} \\
(0.91)\end{array}$ & $\begin{array}{c}\mathbf{0 . 2 4} \\
(0.66)\end{array}$ & -0.86 \\
\hline $\begin{array}{l}\text { Preserved fruits \& } \\
\text { vegetables }\end{array}$ & $\begin{array}{l}\text { Mean profit growth } \\
\text { Standard deviation }\end{array}$ & $\begin{array}{c}\mathbf{0 . 3 0} \\
(0.53)\end{array}$ & $\begin{array}{c}\mathbf{0 . 0 6} \\
(0.34)\end{array}$ & $-1.67 *$ \\
\hline Edible oils \& fats & $\begin{array}{l}\text { Mean profit growth } \\
\text { Standard deviation }\end{array}$ & $\begin{array}{c}\mathbf{0 . 1 7} \\
(0.49)\end{array}$ & $\begin{array}{l}\mathbf{- 0 . 0 1} \\
(0.55)\end{array}$ & $-2.22 * *$ \\
\hline Cigarettes & $\begin{array}{l}\text { Mean profit growth } \\
\text { Standard deviation }\end{array}$ & $\begin{array}{c}\mathbf{0 . 3 0} \\
(0.29)\end{array}$ & $\begin{array}{c}\mathbf{0 . 1 1} \\
(0.25)\end{array}$ & $-2.82 * *$ \\
\hline $\begin{array}{l}\text { Industrial inorganic } \\
\text { chemicals }\end{array}$ & $\begin{array}{l}\text { Mean profit growth } \\
\text { Standard deviation }\end{array}$ & $\begin{array}{c}\mathbf{0 . 1 0} \\
(0.19)\end{array}$ & $\begin{array}{c}\mathbf{0 . 0 2} \\
(0.28)\end{array}$ & -0.88 \\
\hline $\begin{array}{l}\text { Plastics, materials } \\
\& \text { synthetics }\end{array}$ & $\begin{array}{l}\text { Mean profit growth } \\
\text { Standard deviation }\end{array}$ & $\begin{array}{c}\mathbf{0 . 2 5} \\
(0.37)\end{array}$ & $\begin{array}{c}\mathbf{0 . 0 1} \\
(0.50)\end{array}$ & $-3.87 * *$ \\
\hline $\begin{array}{l}\text { Industrial organic } \\
\text { chemicals }\end{array}$ & $\begin{array}{l}\text { Mean profit growth } \\
\text { Standard deviation }\end{array}$ & $\begin{array}{c}\mathbf{0 . 3 7} \\
(0.37)\end{array}$ & $\begin{array}{c}\mathbf{0 . 0 4} \\
(0.43)\end{array}$ & $-3.60 * *$ \\
\hline Fertilizer & $\begin{array}{l}\text { Mean profit growth } \\
\text { Standard deviation }\end{array}$ & $\begin{array}{c}\mathbf{0 . 2 3} \\
(0.45) \\
\end{array}$ & $\begin{array}{c}\mathbf{0 . 0 8} \\
(0.47) \\
\end{array}$ & $-1.66^{*}$ \\
\hline
\end{tabular}

Notes: (a) Operating profits measured as percent change in net sales and revenues less cost of goods sold (measured in local currency).

(b) Devaluing countries are countries with a major devaluation (as defined in Table 2) in the current year.

(c) Z-statistic from a two-sample Wilcoxon rank-sum test if the two groups of firms are from populations with the same distribution. * indicates significance at the 10 percent level and $* *$ indicates significance at the 5 percent level. 


\section{Regression Results: Growth in Firm Operating Profits}

\begin{tabular}{|c|c|c|c|c|c|c|}
\hline \multirow[b]{3}{*}{$\begin{array}{l}\text { Pooled cross- } \\
\text { section }\end{array}$} & \multicolumn{3}{|c|}{ Devaluation Dummies } & \multirow{3}{*}{$\begin{array}{c}\text { Inflation } \\
0.005^{* *} \\
(0.001)\end{array}$} & \multirow{2}{*}{$\begin{array}{c}\# \\
\text { Observs. } \\
\end{array}$} & \multirow{2}{*}{$\mathbf{R}^{2}$} \\
\hline & $t-1$ & $\mathbf{t}$ & $t+1$ & & & \\
\hline & $\begin{array}{c}0.067 \\
(0.049)\end{array}$ & $\begin{array}{c}0.146 * * \\
(0.043)\end{array}$ & $\begin{array}{l}-0.076 \\
(0.072)\end{array}$ & & 2,814 & 0.02 \\
\hline $\begin{array}{l}\text { Fixed industry } \\
\text { effects }\end{array}$ & $\begin{array}{c}0.114 * * \\
(0.048)\end{array}$ & $\begin{array}{c}0.183^{* *} \\
(0.044)\end{array}$ & $\begin{array}{l}-0.026 \\
(0.065)\end{array}$ & $\begin{array}{l}0.005^{* *} \\
(0.001)\end{array}$ & 2,814 & 0.02 \\
\hline $\begin{array}{l}\text { Random industry } \\
\text { effects }\end{array}$ & $\begin{array}{c}0.098^{* *} \\
(0.048)\end{array}$ & $\begin{array}{c}0.170^{* *} \\
(0.044)\end{array}$ & $\begin{array}{l}-0.043 \\
(0.065)\end{array}$ & $\begin{array}{c}0.005^{* *} \\
(0.001)\end{array}$ & 2,814 & 0.02 \\
\hline $\begin{array}{l}\text { Rubber plantations } \\
\& \text { forest products }\end{array}$ & $\begin{array}{c}0.097 \\
(0.196)\end{array}$ & $\begin{array}{c}0.079 \\
(0.232)\end{array}$ & $\begin{array}{c}0.026 \\
(0.347)\end{array}$ & $\begin{array}{c}0.013^{* *} \\
(0.003)\end{array}$ & 68 & 0.09 \\
\hline Silver \& gold ores & $\begin{array}{c}0.293 \\
(0.179)\end{array}$ & $\begin{array}{c}0.193 \\
(0.290)\end{array}$ & $\begin{array}{l}-0.332 \\
(0.392)\end{array}$ & $\begin{array}{c}0.005 \\
(0.010)\end{array}$ & 300 & 0.03 \\
\hline $\begin{array}{l}\text { Natural gas \& } \\
\text { crude petroleum }\end{array}$ & $\begin{array}{l}-0.034 \\
(0.154)\end{array}$ & $\begin{array}{l}-0.243 \\
(0.275)\end{array}$ & $\begin{array}{c}0.723 * * \\
(0.297)\end{array}$ & $\begin{array}{c}0.006^{* *} \\
(0.003)\end{array}$ & 565 & 0.09 \\
\hline $\begin{array}{l}\text { Preserved fruits \& } \\
\text { vegetables }\end{array}$ & $\begin{array}{c}0.169 \\
(0.141)\end{array}$ & $\begin{array}{l}0.247 * \\
(0.145)\end{array}$ & $\begin{array}{l}-0.197 \\
(0.133)\end{array}$ & $\begin{array}{c}0.007 * * \\
(0.002)\end{array}$ & 210 & 0.12 \\
\hline Edible oils \& fats & $\begin{array}{c}0.251 \\
(0.155)\end{array}$ & $\begin{array}{l}0.201^{*} \\
(0.106)\end{array}$ & $\begin{array}{c}0.067 \\
(0.169)\end{array}$ & $\begin{array}{c}0.012 * * \\
(0.002)\end{array}$ & 213 & 0.10 \\
\hline Cigarettes & $\begin{array}{l}-0.102 \\
(0.113)\end{array}$ & $\begin{array}{c}0.139 \\
(0.114)\end{array}$ & $\begin{array}{c}0.006 \\
(0.135)\end{array}$ & $\begin{array}{c}0.003 \\
(0.002)\end{array}$ & 124 & 0.08 \\
\hline $\begin{array}{l}\text { Industrial inorganic } \\
\text { chemicals }\end{array}$ & $\begin{array}{c}0.131^{* *} \\
(0.044)\end{array}$ & $\begin{array}{c}0.135^{* *} \\
(0.063)\end{array}$ & $\begin{array}{c}0.094 \\
(0.102)\end{array}$ & $\begin{array}{l}-0.005 \\
(0.007)\end{array}$ & 377 & 0.04 \\
\hline $\begin{array}{l}\text { Plastics, materials } \\
\& \text { synthetics }\end{array}$ & $\begin{array}{c}0.140 \\
(0.090)\end{array}$ & $\begin{array}{c}0.194 * * \\
(0.067)\end{array}$ & $\begin{array}{l}-0.040 \\
(0.083)\end{array}$ & $\begin{array}{c}0.002 \\
(0.002)\end{array}$ & 477 & 0.04 \\
\hline $\begin{array}{l}\text { Industrial organic } \\
\text { chemicals }\end{array}$ & $\begin{array}{c}0.037 \\
(0.062)\end{array}$ & $\begin{array}{c}0.248^{* *} \\
(0.082)\end{array}$ & $\begin{array}{l}-0.046 \\
(0.076)\end{array}$ & $\begin{array}{c}0.011^{* *} \\
(0.002)\end{array}$ & 251 & 0.11 \\
\hline Fertilizer & $\begin{array}{c}-0.012 \\
(0.073) \\
\end{array}$ & $\begin{array}{c}0.177 \\
(0.127) \\
\end{array}$ & $\begin{array}{c}0.014 \\
(0.170) \\
\end{array}$ & $\begin{array}{l}0.005 * * \\
(0.002) \\
\end{array}$ & 229 & 0.05 \\
\hline
\end{tabular}

Notes: * indicates significance at the 10 percent level and ** indicates significance at the 5 percent level. Standard errors are in parentheses and are White-adjusted for heteroscedasticity. $\mathrm{R}^{2}$ is the within- $\mathrm{R}^{2}$ for the fixed-effects estimates and the overall- $\mathrm{R}^{2}$ for the random-effects estimates. Period dummy variables are included in each specification and are always jointly significant at the 1 percent level. 


\section{Table 11 Sensitivity Analysis: Growth in Firm Operating Profits}

\begin{tabular}{|c|c|c|c|c|c|c|}
\hline & \multicolumn{3}{|c|}{ Devaluation Dummies } & \multirow[b]{2}{*}{ Inflation } & \multirow{2}{*}{$\begin{array}{c}\# \\
\text { Observs. }\end{array}$} & \multirow{2}{*}{$\mathbf{R}^{2}$} \\
\hline & $t-1$ & $\mathbf{t}$ & $t+1$ & & & \\
\hline $\begin{array}{l}\text { Base Estimates } \\
\text { (random effects) }\end{array}$ & $\begin{array}{c}0.098 * * \\
(0.048)\end{array}$ & $\begin{array}{c}0.170^{* *} \\
(0.044)\end{array}$ & $\begin{array}{l}-0.043 \\
(0.065)\end{array}$ & $\begin{array}{c}0.005^{* *} \\
(0.001)\end{array}$ & 2,814 & 0.02 \\
\hline $\begin{array}{l}\text { Exclude natural gas } \\
\& \text { crude petroleum }\end{array}$ & $\begin{array}{c}0.115^{* *} \\
(0.046)\end{array}$ & $\begin{array}{c}0.174^{* *} \\
(0.042)\end{array}$ & $\begin{array}{l}-0.049 \\
(0.062)\end{array}$ & $\begin{array}{l}0.006 * * \\
(0.001)\end{array}$ & 2,249 & 0.03 \\
\hline $\begin{array}{l}\text { Control for firm } \\
\text { size }^{b}\end{array}$ & $\begin{array}{c}0.066 \\
(0.048)\end{array}$ & $\begin{array}{c}0.145^{* *} \\
(0.044)\end{array}$ & $\begin{array}{l}-0.078 \\
(0.065)\end{array}$ & $\begin{array}{c}0.005^{* *} \\
(0.001)\end{array}$ & 2,812 & 0.02 \\
\hline $\begin{array}{l}\text { Inflation based on } \\
\text { producer-price index }^{c}\end{array}$ & $\begin{array}{c}0.064 \\
(0.049)\end{array}$ & $\begin{array}{c}0.192 * * \\
(0.044)\end{array}$ & $\begin{array}{l}-0.050 \\
(0.065)\end{array}$ & $\begin{array}{c}0.002 * * \\
(0.001)\end{array}$ & 2,693 & 0.02 \\
\hline $\begin{array}{l}\text { Include regional } \\
\text { dummy variables }^{\mathrm{d}}\end{array}$ & $\begin{array}{c}0.120^{* *} \\
(0.050)\end{array}$ & $\begin{array}{l}0.201 * * \\
(0.046)\end{array}$ & $\begin{array}{l}-0.020 \\
(0.067)\end{array}$ & $\begin{array}{c}0.005^{* *} \\
(0.001)\end{array}$ & 2,814 & 0.03 \\
\hline $\begin{array}{l}\text { Include country } \\
\text { dummy variables }\end{array}$ & $\begin{array}{c}0.174 * * \\
(0.075)\end{array}$ & $\begin{array}{c}0.268^{* *} \\
(0.083)\end{array}$ & $\begin{array}{c}0.066 \\
(0.092)\end{array}$ & $\begin{array}{c}0.006^{* *} \\
(0.002)\end{array}$ & 2,814 & 0.04 \\
\hline $\begin{array}{l}\text { Only non-OECD } \\
\text { countries }\end{array}$ & $\begin{array}{c}0.180 * * \\
(0.063)\end{array}$ & $\begin{array}{c}0.189 * * \\
(0.063)\end{array}$ & $\begin{array}{l}-0.053 \\
(0.089)\end{array}$ & $\begin{array}{c}0.006^{* *} \\
(0.002)\end{array}$ & 847 & 0.04 \\
\hline $\begin{array}{l}\text { Only middle income } \\
\text { countries }^{\mathrm{e}}\end{array}$ & $\begin{array}{l}0.123^{*} \\
(0.069)\end{array}$ & $\begin{array}{c}0.168^{* *} \\
(0.071)\end{array}$ & $\begin{array}{l}-0.106 \\
(0.103)\end{array}$ & $\begin{array}{c}0.006^{* *} \\
(0.002)\end{array}$ & 616 & 0.04 \\
\hline $\begin{array}{l}\text { Only low-income } \\
\text { countries }^{\text {e }}\end{array}$ & $\begin{array}{c}0.205 \\
(0.169)\end{array}$ & $\begin{array}{l}0.221^{*} \\
(0.116)\end{array}$ & $\begin{array}{l}--- \\
---\end{array}$ & $\begin{array}{c}0.006^{* *} \\
(0.003)\end{array}$ & 303 & 0.07 \\
\hline Only Asia ${ }^{\mathrm{f}}$ & $\begin{array}{l}0.090^{*} \\
(0.047)\end{array}$ & $\begin{array}{c}0.148 * * \\
(0.040)\end{array}$ & $\begin{array}{c}0.021 \\
(0.056)\end{array}$ & $\begin{array}{c}0.005^{* *} \\
(0.002)\end{array}$ & 1,170 & 0.03 \\
\hline $\begin{array}{l}\text { SUR joint estimation } \\
\text { with profit growth }\end{array}$ & $\begin{array}{l}0.114 * * \\
(0.048)\end{array}$ & $\begin{array}{l}0.183 * * \\
(0.044)\end{array}$ & $\begin{array}{l}-0.026 \\
(0.065)\end{array}$ & $\begin{array}{c}0.005 * * \\
(0.001)\end{array}$ & 2,814 & 0.04 \\
\hline
\end{tabular}

Notes: * indicates significance at the 10 percent level and ** indicates significance at the 5 percent level. Standard errors are in parentheses and are White-adjusted for heteroscedasticity. All estimates are random (industry) effects. $\mathrm{R}^{2}$ is the overall- $\mathrm{R}^{2}$. Period dummy variables are included in each specification.

(a) Excludes natural gas and crude petroleum (SIC group 131).

(b) Firm size measured as total assets in U.S. dollars.

(c) Producer-price index based on line 63..zf in International Monetary Fund (2001). Monthly data corresponds to company's reporting period.

(d) Regional dummy variables are the based on the 9 regions listed in Table 3.

(e) Definitions of middle- and low-income countries are based on World Bank (2000).

(f) Includes East Asia and South/West Asia, as defined in Table 3.

(g) Results from a seemingly-unrelated regressions model including both output growth and profit growth. Coefficient estimates for the output growth equation are reported in Table 7. 


\section{Table 12}

\section{Trends in Capital Investment Growth ${ }^{\mathrm{a}}$ : Devaluing Countries versus Rest of World}

\begin{tabular}{|c|c|c|c|c|}
\hline & & $\begin{array}{l}\text { Firms in } \\
\text { devaluing } \\
\text { countries }^{b}\end{array}$ & $\begin{array}{l}\text { Firms in } \\
\text { rest of } \\
\text { world } \\
\end{array}$ & $\begin{array}{l}\text { Z-statistic for } \\
\text { difference in } \\
\text { capital growth }^{\mathrm{c}}\end{array}$ \\
\hline Full sample & $\begin{array}{l}\text { Mean capital growth } \\
\text { Standard deviation }\end{array}$ & $\begin{array}{c}\mathbf{0 . 1 4} \\
(0.43)\end{array}$ & $\begin{array}{c}\mathbf{0 . 1 3} \\
(0.61)\end{array}$ & -0.81 \\
\hline $\begin{array}{l}\text { Rubber plantations } \\
\& \text { forest products }\end{array}$ & $\begin{array}{l}\text { Mean capital growth } \\
\text { Standard deviation }\end{array}$ & $\begin{array}{c}\mathbf{0 . 1 1} \\
(0.40)\end{array}$ & $\begin{array}{c}\mathbf{0 . 2 5} \\
(0.71)\end{array}$ & -0.78 \\
\hline Silver \& gold ores & $\begin{array}{l}\text { Mean capital growth } \\
\text { Standard deviation }\end{array}$ & $\begin{array}{c}\mathbf{0 . 2 9} \\
(1.12)\end{array}$ & $\begin{array}{c}\mathbf{0 . 2 0} \\
(1.16)\end{array}$ & -0.60 \\
\hline $\begin{array}{l}\text { Natural gas \& } \\
\text { crude petroleum }\end{array}$ & $\begin{array}{l}\text { Mean capital growth } \\
\text { Standard deviation }\end{array}$ & $\begin{array}{c}\mathbf{0 . 2 8} \\
(0.28)\end{array}$ & $\begin{array}{c}\mathbf{0 . 2 2} \\
(0.58)\end{array}$ & -1.01 \\
\hline $\begin{array}{l}\text { Preserved fruits \& } \\
\text { vegetables }\end{array}$ & $\begin{array}{l}\text { Mean capital growth } \\
\text { Standard deviation }\end{array}$ & $\begin{array}{c}\mathbf{0 . 0 4} \\
(0.24)\end{array}$ & $\begin{array}{c}\mathbf{0 . 0 8} \\
(0.26)\end{array}$ & 1.00 \\
\hline Edible oils \& fats & $\begin{array}{l}\text { Mean capital growth } \\
\text { Standard deviation }\end{array}$ & $\begin{array}{c}\mathbf{0 . 0 7} \\
(0.29)\end{array}$ & $\begin{array}{c}\mathbf{0 . 0 6} \\
(0.27)\end{array}$ & -0.56 \\
\hline Cigarettes & $\begin{array}{l}\text { Mean capital growth } \\
\text { Standard deviation }\end{array}$ & $\begin{array}{c}\mathbf{0 . 1 6} \\
(0.11)\end{array}$ & $\begin{array}{c}\mathbf{0 . 1 0} \\
(0.23)\end{array}$ & $-1.73^{*}$ \\
\hline $\begin{array}{l}\text { Industrial inorganic } \\
\text { chemicals }\end{array}$ & $\begin{array}{l}\text { Mean capital growth } \\
\text { Standard deviation }\end{array}$ & $\begin{array}{c}\mathbf{0 . 0 8} \\
(0.28)\end{array}$ & $\begin{array}{c}\mathbf{0 . 0 8} \\
(0.24)\end{array}$ & -0.36 \\
\hline $\begin{array}{l}\text { Plastics, materials } \\
\& \text { synthetics }\end{array}$ & $\begin{array}{l}\text { Mean capital growth } \\
\text { Standard deviation }\end{array}$ & $\begin{array}{c}\mathbf{0 . 0 9} \\
(0.33)\end{array}$ & $\begin{array}{c}\mathbf{0 . 0 9} \\
(0.47)\end{array}$ & 0.82 \\
\hline $\begin{array}{l}\text { Industrial organic } \\
\text { chemicals }\end{array}$ & $\begin{array}{l}\text { Mean capital growth } \\
\text { Standard deviation }\end{array}$ & $\begin{array}{c}\mathbf{0 . 1 3} \\
(0.28)\end{array}$ & $\begin{array}{c}\mathbf{0 . 0 6} \\
(0.50)\end{array}$ & 0.18 \\
\hline Fertilizer & $\begin{array}{l}\text { Mean capital growth } \\
\text { Standard deviation }\end{array}$ & $\begin{array}{c}\mathbf{0 . 2 0} \\
(0.30)\end{array}$ & $\begin{array}{c}\mathbf{0 . 1 0} \\
(0.29)\end{array}$ & $-1.73^{*}$ \\
\hline
\end{tabular}

Notes: (a) Growth in capital investment measured as percent change in plant, property and equipment.

(b) Devaluing countries are countries with a major devaluation (as defined in Table 2) in the current year.

(c) Z-statistic from a two-sample Wilcoxon rank-sum test if the two groups of firms are from populations with the same distribution. * indicates significance at the 10 percent level and $* *$ indicates significance at the 5 percent level. 
Table 13

\section{Capital Investment and Stock Returns in Devaluing Countries ${ }^{\mathrm{a}}$ : Trends Based on Interest Rates and Capital/Labor Ratios}

\begin{tabular}{|c|c|c|c|c|}
\hline & $\begin{array}{l}\text { Mean growth in } \\
\text { capital investment }\end{array}$ & $\begin{array}{c}\# \\
\text { of firms }\end{array}$ & $\begin{array}{l}\text { Mean 3-month } \\
\text { return }^{c}\end{array}$ & $\begin{array}{c}\# \\
\text { of firms }\end{array}$ \\
\hline$\Delta \mathrm{r}<15 \%{ }^{\mathrm{d}}$ & 0.14 & 144 & -0.08 & 168 \\
\hline$\Delta \mathrm{r} \geq 15 \%{ }^{\mathrm{d}}$ & 0.13 & 58 & -0.32 & 53 \\
\hline $\mathrm{K} /$ L Ratio $<400^{\mathrm{d}}$ & 0.15 & 143 & -0.13 & 171 \\
\hline $\mathrm{K} / \mathrm{L}$ Ratio $\geq 400^{\mathrm{d}}$ & 0.11 & 59 & -0.17 & 50 \\
\hline$\Delta r<15 \% \& K / L$ Ratio $<400^{\mathrm{d}}$ & 0.15 & 110 & -0.06 & 127 \\
\hline$\Delta \mathrm{r}<15 \%$ \& K/L Ratio $\geq 400^{\mathrm{d}}$ & 0.11 & 34 & -0.12 & 41 \\
\hline$\Delta \mathrm{r} \geq 15 \% \& \mathrm{~K} / \mathrm{L}$ Ratio $<400^{\mathrm{d}}$ & 0.13 & 33 & -0.28 & 44 \\
\hline$\Delta r \geq 15 \%$ \& K/L Ratio $\geq 400^{\mathrm{d}}$ & 0.10 & 25 & -0.29 & 9 \\
\hline
\end{tabular}

\section{Notes:}

(a) Devaluation events are listed in Table 2.

(b) Growth in capital investment measured as percent change in plant, property, and equipment.

(c) Returns are based on local currency and are calculated from the first day of the month prior to the devaluation to the last day of the month after the devaluation.

(d) $\Delta r$ is the change in the lending interest rate as reported in the IFS. K/L ratio is the ratio of total assets (denominated in dollars) to employees. 


\section{Table 14 \\ 3-Month Stock Returns in Devaluing Countries ${ }^{\mathrm{a}}$ Trends Based on Capital/Labor Ratios}

\begin{tabular}{|c|c|c|c|}
\hline & & $\begin{array}{c}\text { Low K/L } \\
\text { Ratio }^{b}\end{array}$ & $\begin{array}{c}\text { High K/L } \\
\text { Ratiob }^{b}\end{array}$ \\
\hline $\begin{array}{l}\text { Brazil } \\
\text { Jan. } 1999\end{array}$ & $\begin{array}{l}\text { Mean 3-month return } \\
\text { Standard deviation }\end{array}$ & $\begin{array}{l}\mathbf{- 0 . 0 8} \\
(0.57)\end{array}$ & $\begin{array}{l}\mathbf{- 0 . 1 7} \\
(0.29)\end{array}$ \\
\hline $\begin{array}{l}\text { Indonesia } \\
\text { Oct. } 1997\end{array}$ & $\begin{array}{l}\text { Mean 3-month return } \\
\text { Standard deviation }\end{array}$ & $\begin{array}{l}\mathbf{- 0 . 0 8} \\
(0.19)\end{array}$ & $\begin{array}{l}\mathbf{- 0 . 3 0} \\
(0.40)\end{array}$ \\
\hline $\begin{array}{l}\text { Korea } \\
\text { Dec. } 1997\end{array}$ & $\begin{array}{l}\text { Mean 3-month return } \\
\text { Standard deviation }\end{array}$ & $\begin{array}{l}\mathbf{- 0 . 0 9} \\
(0.33)\end{array}$ & $\begin{array}{l}\mathbf{- 0 . 3 0} \\
(0.41)\end{array}$ \\
\hline $\begin{array}{l}\text { Malaysia } \\
\text { Jan. } 1998\end{array}$ & $\begin{array}{l}\text { Mean 3-month return } \\
\text { Standard deviation }\end{array}$ & $\begin{array}{c}\mathbf{0 . 1 0} \\
(0.31)\end{array}$ & $\begin{array}{c}\mathbf{0 . 2 6} \\
(0.24)\end{array}$ \\
\hline $\begin{array}{l}\text { Philippines } \\
\text { Dec. } 1997\end{array}$ & $\begin{array}{l}\text { Mean 3-month return } \\
\text { Standard deviation }\end{array}$ & $\begin{array}{l}\mathbf{- 0 . 4 7} \\
(0.27)\end{array}$ & $\begin{array}{l}\mathbf{- 0 . 3 3} \\
(0.40)\end{array}$ \\
\hline $\begin{array}{l}\text { Russia } \\
\text { Aug. } 1998\end{array}$ & $\begin{array}{l}\text { Mean 3-month return } \\
\text { Standard deviation }\end{array}$ & $\begin{array}{l}\mathbf{- 0 . 7 4} \\
(1.10)\end{array}$ & $\begin{array}{l}\mathbf{- 1 . 3 0} \\
(1.42)\end{array}$ \\
\hline $\begin{array}{l}\text { South Africa } \\
\text { July } 1998\end{array}$ & $\begin{array}{l}\text { Mean 3-month return } \\
\text { Standard deviation }\end{array}$ & $\begin{array}{l}\mathbf{- 0 . 1 7} \\
(0.30)\end{array}$ & $\begin{array}{l}\mathbf{- 0 . 3 0} \\
(0.29)\end{array}$ \\
\hline $\begin{array}{l}\text { Thailand } \\
\text { July } 1997\end{array}$ & $\begin{array}{l}\text { Mean 3-month return } \\
\text { Standard deviation }\end{array}$ & $\begin{array}{l}\mathbf{- 0 . 1 2} \\
(0.59)\end{array}$ & $\begin{array}{l}\mathbf{- 0 . 2 9} \\
(0.54)\end{array}$ \\
\hline $\begin{array}{l}\text { Unweighted Mean }{ }^{c} \\
\text { Weighted Mean }^{c}\end{array}$ & & $\begin{array}{l}-0.21 \\
-0.15 \\
\end{array}$ & $\begin{array}{l}-0.34 \\
-0.20 \\
\end{array}$ \\
\hline
\end{tabular}

Notes: (a) Returns are based on local currency and are calculated from the first day of the month prior to the devaluation to the last day of the month after the devaluation. The devaluation month is listed under the country.

(b) Sample divided based on median $\mathrm{K} / \mathrm{L}$ ratio for the given country in the relevant year. $\mathrm{K} / \mathrm{L}$ ratio is the ratio of total assets (in U.S. dollars) to total employees.

(c) Unweighted is the average across countries. Weighted is the average across countries weighted by the number of firms in each country. 
Table 15

K/L Ratios and Annual Stock Returns in Non-Devaluing Countries

\begin{tabular}{|c|c|c|c|}
\hline & \multirow{2}{*}{$\begin{array}{c}\text { Devaluing } \\
\text { Countries } \\
\text { Mean } \mathbf{K} / \mathbf{L}^{\mathrm{a}} \\
\end{array}$} & \multicolumn{2}{|c|}{$\begin{array}{c}\text { Mean Annual Return } \\
\text { in Non-Devaluing Countries }\end{array}$} \\
\hline & & 06/97-06/98 & 07/98-07/99 \\
\hline Silver \& gold ores & $\begin{array}{c}\mathbf{5 1} \\
(16) \\
47\end{array}$ & $\begin{array}{c}\mathbf{- 0 . 6 6} \\
(0.65) \\
118\end{array}$ & $\begin{array}{c}\mathbf{- 0 . 4 1} \\
(0.72) \\
116\end{array}$ \\
\hline $\begin{array}{l}\text { Rubber plantations } \\
\& \text { forest products }\end{array}$ & $\begin{array}{c}\mathbf{1 0 7} \\
(173) \\
19\end{array}$ & $\begin{array}{c}\mathbf{- 0 . 1 5} \\
(0.29) \\
7\end{array}$ & $\begin{array}{c}\mathbf{- 0 . 3 3} \\
(0.27) \\
7\end{array}$ \\
\hline Cigarettes & $\begin{array}{c}\mathbf{1 3 9} \\
(84) \\
17\end{array}$ & $\begin{array}{c}\mathbf{0 . 1 3} \\
(0.40) \\
25\end{array}$ & $\begin{array}{c}\mathbf{0 . 3 1} \\
(0.31) \\
24\end{array}$ \\
\hline Edible oils \& fats & $\begin{array}{c}\mathbf{1 5 0} \\
(110) \\
32\end{array}$ & $\begin{array}{c}\mathbf{- 0 . 2 3} \\
(0.50) \\
33\end{array}$ & $\begin{array}{c}\mathbf{- 0 . 0 3} \\
(0.56) \\
34\end{array}$ \\
\hline Fertilizer & $\begin{array}{c}356 \\
(170) \\
29\end{array}$ & $\begin{array}{c}\mathbf{- 0 . 1 0} \\
(0.45) \\
60\end{array}$ & $\begin{array}{c}\mathbf{- 0 . 0 4} \\
(0.39) \\
55\end{array}$ \\
\hline $\begin{array}{l}\text { Industrial inorganic } \\
\text { chemicals }\end{array}$ & $\begin{array}{c}\mathbf{3 8 2} \\
(350) \\
20\end{array}$ & $\begin{array}{c}\mathbf{- 0 . 2 0} \\
(0.40) \\
95\end{array}$ & $\begin{array}{c}\mathbf{- 0 . 0 5} \\
(0.30) \\
96\end{array}$ \\
\hline $\begin{array}{l}\text { Preserved fruits \& } \\
\text { vegetables }\end{array}$ & $\begin{array}{c}395 \\
(520) \\
16\end{array}$ & $\begin{array}{c}\mathbf{- 0 . 0 2} \\
(0.42) \\
58\end{array}$ & $\begin{array}{c}\mathbf{- 0 . 0 2} \\
(0.64) \\
56\end{array}$ \\
\hline $\begin{array}{l}\text { Plastics, materials } \\
\& \text { synthetics }\end{array}$ & $\begin{array}{c}\mathbf{4 9 2} \\
(394) \\
70\end{array}$ & $\begin{array}{c}\mathbf{- 0 . 1 3} \\
(0.46) \\
115\end{array}$ & $\begin{array}{c}\mathbf{0 . 0 1} \\
(0.43) \\
110\end{array}$ \\
\hline $\begin{array}{l}\text { Industrial organic } \\
\text { chemicals }\end{array}$ & $\begin{array}{c}\mathbf{5 9 2} \\
(186) \\
34\end{array}$ & $\begin{array}{c}\mathbf{- 0 . 1 6} \\
(0.51) \\
67\end{array}$ & $\begin{array}{c}\mathbf{- 0 . 1 2} \\
(0.41) \\
63\end{array}$ \\
\hline $\begin{array}{l}\text { Natural gas \& } \\
\text { crude petroleum }\end{array}$ & $\begin{array}{c}\mathbf{1 1 9 1} \\
(1579) \\
29\end{array}$ & $\begin{array}{c}\mathbf{- 0 . 1 1} \\
(0.48) \\
181\end{array}$ & $\begin{array}{c}\mathbf{- 0 . 2 8} \\
(0.70) \\
174\end{array}$ \\
\hline $\begin{array}{c}\text { Unweighted Mean } \\
\text { Low } K / L \\
\text { High } K / L\end{array}$ & $\begin{array}{l}160 \\
610\end{array}$ & $\begin{array}{l}-0.20 \\
-0.12\end{array}$ & $\begin{array}{l}-0.10 \\
-0.09\end{array}$ \\
\hline $\begin{array}{c}\text { Weighted Mean } \\
\text { Low } K / L \\
\text { High } K / L\end{array}$ & $\begin{array}{l}152 \\
610\end{array}$ & $\begin{array}{l}-0.37 \\
-0.13\end{array}$ & $\begin{array}{r}-0.19 \\
-0.12\end{array}$ \\
\hline
\end{tabular}

Notes: Standard deviations are listed in parentheses. Number of firms is listed below standard deviations. (a) Capital/labor ratios measured as the ratio of total assets (in U.S. dollars) to total employees.

(b) Non-devaluing countries defined as countries that did not have a major devaluation (as listed in Table 2) in the current year or previous year.

(c) Unweighted is the average across industries. Weighted is the average across industries weighted by the number of firms in each industry. 